\title{
Response to nitrogen and salinity in Rhizophora mangle propagules varies by maternal family and population of origin
}

\author{
1 Christina L. Richards ${ }^{1,2 \dagger *^{*}}$, Kristen L. Langanke ${ }^{1 \dagger}$, Jeannie Mounger ${ }^{1}$, Gordon A. Fox ${ }^{1,3}$, David \\ 2 B. Lewis ${ }^{1+}$ \\ $3{ }^{1}$ Department of Integrative Biology, Tampa, FL, USA \\ $4 \quad{ }^{2}$ Plant Evolutionary Ecology Group, University of Tu $\square$ bingen, $\mathrm{Tu} \square$ bingen, Germany \\ $5 \quad{ }^{3}$ Biology Department, University of New Mexico, Albuquerque, NM, USA \\ $6 \quad{ }^{\dagger}$ These authors share first authorship \\ $7 \quad$ These authors have contributed equally to this work and share senior authorship \\ 8 * Correspondence: \\ 9 Christina L. Richards \\ 10 clr@usf.edu
}

11 Keywords: coastal ecosystems, conservation genetics, foundation species, phenotypic plasticity, 12 mangroves, Rhizophora mangle.

\section{Abstract}

14 Many coastal foundation plant species thrive across a range of environmental conditions, often 15 displaying dramatic phenotypic variation in response to environmental variation. We characterized

16 the response of propagules from six populations of the foundation species Rhizophora mangle L. to

17 full factorial combinations of two levels of salt (15 ppt and $45 \mathrm{ppt}$ ) reflecting the range of salinity

18 measured in the field populations, and two levels of nitrogen (N; no addition and amended at

19 approximately $3 \mathrm{mg} \mathrm{N}$ per pot each week) equivalent to comparing ambient $\mathrm{N}$ to a rate of addition of

$2075 \mathrm{~kg}$ per hectare per year. The response to increasing salt included significant plasticity in

21 succulence. Propagules also showed plasticity in maximum photosynthetic rate in response to $\mathrm{N}$ amendment, but the responses depended on the level of salt and varied by population of origin. Generally, survival was lower in high salt and high N, but the impact varied among populations. Overall, this study revealed significant phenotypic plasticity in response to salt and $\mathrm{N}$ level. Propagules from different populations differed in all traits measured. Variation in phenotypic plasticity and propagule survival in $R$. mangle may contribute to adaptation to a complex mosaic of 


\section{INTRODUCTION}

29

30

31

32

33

34

35

36

37

38

39

40

41

42

43

44

45

46

47

48

49

50

51

52

53

54

55

56

57

58

59

60

61

62

63

64

65

66

67

68

69

70

71

72

Many plant species thrive across an extensive range of environmental conditions, often displaying dramatic phenotypic variation (McKee, 1995; Smith and Snedaker, 1995; Richards et al., 2005; Feller et al., 2010). This is particularly true in coastal ecosystems that are marked by temporal cycles and spatial variation in tidal inundation, temperature, nutrient availability, and salinity (Pennings and Bertness, 2001; Krauss et al., 2008; IPCC, 2014; Proffitt and Travis, 2014; Wuebbles et al., 2014). In addition to the naturally dynamic habitat of coastal systems, anthropogenic activities can increase the input of nutrients and alter watersheds, further contributing to environmental variation (Bertness et al., 2002; Barbier et al., 2008; Gedan et al., 2009, 2011; Crotty et al., 2020). Within these dynamic conditions, foundation plant species, like mangroves, provide ecosystem services, such as habitat for many juvenile fish species, biotic filters of pollutants, and storm buffers (Ellison et al., 2005; Zedler and Kercher, 2005; IUCN, 2007; Alongi, 2008, 2013; Costanza et al., 2008; Gedan et al., 2011). Foundation species are defined not only as those that dominate a community assemblage numerically or in biomass, but they also determine diversity of associated taxa through a variety of interactions (Ellison, 2019). Further, foundation species modulate fluxes of nutrients and energy in their ecosystem (Ellison, 2019). Hence, these species disproportionately contribute to maintaining habitat integrity and ecosystem resilience (Bertness and Callaway, 1994; Keith et al., 2017; Ellison, 2019; Bertness, 2020; Qiao et al., 2021). Understanding how these species cope with challenges from anthropogenic impacts is key to preserving the ecosystems they create and define (Guo et al., 2021).

Understanding the mechanisms of response in coastal foundation species has become increasingly important for conservation and management strategies as these species must cope with rising sea levels and increased warming due to global change (Gedan et al., 2011; Kirwan and Megonigal, 2013; Osland et al., 2013, 2017). The Food and Agriculture Organization of the United Nations (FAO) estimates that as much as $35 \%$ of global mangrove forest habitat has been destroyed since roughly 1980 for the development of human settlements, agriculture and aquaculture, and industrial shipping harbors, although the rate of loss appears to have slowed in the last decade (Food and Agriculture Organization of the United Nations, 2007; Polidoro et al., 2010; Ellison et al., 2015; Global forest resources assessment 2020, 2020). In some regions, mangrove trees are also harvested for wood and charcoal (Ellison et al., 2015), resulting in habitat fragmentation and isolation of existing remnant fragments (Friess et al., 2012; Haddad et al., 2015). The resultant loss of diversity could pose risks for these coastal foundation species in the future, particularly as sea levels are projected to rise between 0.2 and $2 \mathrm{~m}$ over the next century due to anthropogenic climate change (Melillo et al., 2014).

The vulnerability of coastal foundation plant communities to global change has been debated. Several authors have suggested that the combination of eutrophication and sea-level rise may result in synergistic losses and requires further research (Deegan et al., 2012; Kirwan and Megonigal, 2013; Kirwan et al., 2016; Crosby et al., 2017; Schuerch et al., 2018). While coastal eutrophication may enhance growth of foundation species, nutrient enrichment studies report a range of impacts on coastal systems depending on the local conditions (Anisfeld and Hill, 2012; Kirwan and Megonigal, 2013). Local sediment characteristics, soil nutrients, microbial processes, and shifts in allocation of the plant species can impact future nutrient cycling and marsh stability (McKee et al., 2007; Turner, 2011; Deegan et al., 2012; Lewis et al., 2021).

Predicting species level responses to environmental challenges requires an understanding of the amount of phenotypic variation within and among populations, which may reflect both phenotypic plasticity and heritable differences in phenotype (Richards et al., 2006; Nicotra et al., 2010; Banta 
and Richards, 2018). Several studies have shown that species harbor heritable differences in ecophysiological traits (Arntz and Delph, 2001; Geber and Griffen, 2003; Caruso et al., 2005), and variation in plasticity of traits (Sultan, 2001; Matesanz and Sultan, 2013; Nicotra et al., 2015; Matesanz et al., 2021). However, the amount of variation in natural populations for traits that are important for response to future climates is not well known (Davis and Shaw, 2001; Parmesan, 2006). Plants that inhabit coastal and intertidal zones have putative physiological adaptations that enable them to grow and reproduce in the anoxic and saline conditions that characterize these habitats. These adaptations include reduction of water required by the plant, adjustment of carbon uptake and nutrient absorption, and changes in resource allocation (Antlfinger and Dunn, 1979; Cavalieri and Huang, 1979; Antlfinger and Dunn, 1983; Glenn and O'Leary, 1984; Donovan et al., 1996, 1997; Flowers and Colmer, 2008). In addition, mangrove species can moderate anoxia that results from flooding via root growth, and altered peat formation has allowed mangrove communities to keep pace with sea level rise (McKee et al., 2007). Mangroves have been shown to respond to changes in nitrogen $(\mathrm{N})$ by altering relative growth rate, photosynthetic rate, and resource allocation (Feller, 1995; McKee, 1995; Feller et al., 2003), which could be an important response to anthropogenic activities, such as runoff from agriculture and other types of land use change (Feller et al., 2003; Alongi, 2013).

Given spatial differences in salinity, anoxia, and $\mathrm{N}$ in the intertidal habitat, plasticity of traits that allow for tolerating such conditions may be adaptive. We expect intertidal plants like mangroves to show plasticity in response to salinity and N conditions. Profitt \& Travis (Proffitt and Travis, 2010) found plasticity in growth rate and reproductive output within and among natural Rhizophora mangle mangrove populations in the Tampa Bay region. However, they also found both site of origin and maternal tree of origin affected $R$. mangle growth and survival, and that these effects varied by intertidal position (significant maternal family by elevation interaction; (Proffitt and Travis, 2010)). On the other hand, we found that nearby populations had low genetic diversity, and little population differentiation. Instead we discovered high epigenetic diversity based on DNA methylation polymorphisms (Mounger et al., 2021). This type of epigenetic diversity has been associated with phenotypic and functional diversity, and could be a mechanism underlying phenotypic plasticity (Zhang et al., 2013; Nicotra et al., 2015; Herrera et al., 2017; Jueterbock et al., 2020). Several studies suggest that epigenetic diversity could be particularly important in genetically depauperate species, providing a nongenetic source of response to the diverse conditions experienced by these populations (Gao et al., 2010; Verhoeven et al., 2010; Richards et al., 2012; Jueterbock et al., 2020). Further, some epigenetic differences have been shown to be heritable. In fact, we discovered that the differences in DNA methylation in $R$. mangle propagules were predicted by maternal tree suggesting a high degree of heritability of differences in DNA methylation (Mounger et al., 2021).

In this study, we characterized within and among population level variation in putative adaptive traits in response to combinations of salinity and $\mathrm{N}$ in a full factorial design. Given the dynamic environment inhabited by $R$. mangle and the evidence of heritable nongenetic differences among populations, we predicted differences in response to salinity and $\mathrm{N}$ amendment treatments among propagules collected from different populations. Our study was designed to test three predictions. First, $R$. mangle seedlings will be plastic in response to salinity and $\mathrm{N}$ amendment in putative adaptive traits that conserve water and adjust allocation of N. Second, response to salinity and N amendment will co-vary as plants shift resources to maintain osmotic balance. Finally, populations will vary in putative adaptive traits, and in plasticity of these traits, due to population differentiation. 


\section{Study species}

119 The red mangrove, Rhizophora mangle L. 1753 (Malpighiales, Rhizophoraceae), is an evergreen shrub or tree found along tropical and subtropical coastlines across the Americas, East Africa, Bermuda, and on a number of outlying islands across the South Pacific (Proffitt and Travis, 2014; Tomlinson, 2016; DeYoe et al., 2020) that can grow to heights of twenty-four meters (Bowman, 1917). Poleward expansion of the species is limited by freezing events (its current northern range limit is roughly $29^{\circ} \mathrm{N}$ latitude; (Proffitt and Travis, 2014; Kennedy et al., 2017). It is considered a self-compatible species, with selfing rates in Tampa Bay estimated to be as high as $80-100 \%$ (Proffitt and Travis, 2005; Nadia and Machado, 2014). However, colder temperatures and contaminants from anthropogenic sources correspond with increased flowering and outcrossing, potentially resulting in higher genetic diversity particularly in the smaller populations at range limits from $28-30^{\circ} \mathrm{N}$ (Proffitt and Travis, 2005, 2014). Rhizophora mangle stands in our study area have a mean number of about 600 reproducing trees per kilometer of estuary (Proffitt and Travis, 2014). Pollinated R. mangle flowers mature in approximately 95 days, producing the buoyant hypocotyl also known as a propagule (Raju Aluri, 2013). The viviparous propagule germinates and matures on the maternal tree before it drops off, is dispersed pelagically, and becomes established as a seedling (McKee, 1995). Rhizophora mangle excludes salt in the root system through selective uptake of potassium $\left(\mathrm{K}^{+}\right)$to sodium $\left(\mathrm{Na}^{+}\right)$ions (Wise and Juncosa, 1989; Flowers and Colmer, 2008; Krauss et al., 2008; Medina et al., 2015), and allocates resources to manage osmotic potential (Bowman, 1917; Flowers and Colmer, 2008).

\section{Sampling design}

139 We sampled six populations of $R$. mangle between June 9 and June 26 of 2015, on the west coast of central Florida (USA) within the following county and state parks: Anclote Key Preserve State Park (AC), Fort De Soto Park (FD), Honeymoon Island State Park (HI), Upper Tampa Bay Conservation Park (UTB), Weedon Island Preserve (WI), and Werner-Boyce Salt Springs State Park (WB) (Figure 1). The sites varied in salinity, mean tidal range, and neighboring species. We measured salinity at each site with a refractometer finding that salinity ranged from 20 to 40 parts per thousand (ppt) across the sites at the time of collection. This area has a humid subtropical climate with mean monthly temperatures ranging from $15.6{ }^{\circ} \mathrm{C}$ in January to $28.5^{\circ} \mathrm{C}$ in August (1991-2020 monthly normals, U.S. NOAA National Centers for Environmental Information, station GHCND:USC00088824, Tarpon Springs, Florida), and annual precipitation of $1379 \mathrm{~mm}$ (annual mean 1991-2020, Tarpon Springs station). Precipitation falls as rain, with $60 \%$ falling during June through September, and $40 \%$ evenly distributed among other months. Monthly mean relative humidity ranges from $67 \%$ in April and May to $76 \%$ in August and September (1948-2018, U.S. NOAA Comparative Climate Data for the United States through 2018, station GHCND:USW00012842, Tampa International Airport). Tides are semi-diurnal, with 0.57 m median amplitudes (U.S. NOAA National Ocean Service, Clearwater Beach, Florida, station 8726724). Sealevel rise is $4.0 \pm 0.6 \mathrm{~mm}$ per year (1973-2020 trend, mean $\pm 95 \%$ confidence interval, NOAA NOS Clearwater Beach station).

157 Honeymoon Island had a near monoculture of $R$. mangle while the remaining sites contained 158 mixtures of two other mangrove species that are common in Florida: Laguncularia racemosa L. and Avicennia germinans L.. We refer to plants from different sites as members of different populations based on our previous work which found differences among sites based on molecular markers (Mounger et al., 2021). At each population, we collected 20 propagules directly from each of 10 maternal trees separated by at least $10 \mathrm{~m}$ from each other to maximize the range of genetic variation 
sampled within each population (Albrecht et al., 2013). Propagules from each maternal tree were at least half-siblings but they could be more closely related due to the high selfing rate in the study area (Proffitt and Travis, 2005) .

166 We refrigerated the propagules at $4{ }^{\circ} \mathrm{C}$ for up to 14 days until we planted them in the greenhouse at the University of South Florida Botanical Gardens. In the greenhouse, propagules from four of the maternal trees at AC and nine of the maternal trees at FD failed to establish, so we returned to sample propagules and maternal tissue from 8 new maternal trees at FD on August 12 and 29, and from the same original maternal trees at AC on October 17. Hence, while most of the propagules were in the greenhouse from the end of June until mid-October before they were exposed to treatments, propagules from these maternal families had less acclimation time before treatments began.

\section{Experimental treatments}

174 We measured the length of each propagule and planted each in a 0.5-liter pot with a 50:50 mixture of sand and peat soil. We watered the plants each day with tap water until we started applying the salinity and $\mathrm{N}$ amendment in mid-October. We set up the experiment in five spatial blocks. Within each block we randomized the position of plants such that each block had one replicate of each family for each treatment combination (i.e., a full factorial randomized complete block design with $\mathrm{N}=6$ populations $\times 10$ maternal families $\times 4$ environmental treatment combinations [ 2 salinity $\times 2 \mathrm{~N}$ fertilization] x 5 blocks $x 1$ replicate/block $=1200$ plants). The treatments were a factorial combination of low and high salt with either no addition or addition of $\mathrm{N}$. The salt treatments were made with Morton solar salt $(\mathrm{NaCl})$. The low salt treatment was $15 \mathrm{ppt}$ and the high salt was $45 \mathrm{ppt}$, reflecting a slightly wider range of salinity than we measured in the field sites. The $\mathrm{N}$ treatments were made from two moles of $\mathrm{N}$ from urea $\left(\mathrm{NH}_{4} \mathrm{Cl}\right)$ and one mole from ammonium nitrate $\left(\mathrm{NH}_{4} \mathrm{NO}_{3}\right)$ in tap water approximating $3 \mathrm{mg} \mathrm{N}$ per pot each week. This level is similar to a rate of $75 \mathrm{~kg} \mathrm{~N}$ per hectare per year, based on an estimated rate of loss by soil erosion and water runoff from corn crop residue in the United States (Pimentel et al. 1989).

At the start of treatments, we recorded seedling initial height from the soil to end of any growth. To avoid osmotic shock, the salinity treatment was applied twice a week and gradually increased by five ppt each treatment. The low salt level (15 ppt) was reached in two weeks and the high salt level (45 ppt) in six weeks. We started $\mathrm{N}$ treatments after the first week (when salinity treatments were $10 \mathrm{ppt}$ ), and applied $\mathrm{N}$ once per week from October 15, 2015-May 1, 2016. We watered on non-treatment days with enough water to saturate the soil, but not flow through. Once per week, we watered with sufficient water to flow through the soil to prevent salt buildup. To determine if the $\mathrm{N}$ amendment was lost between treatments, we collected the flow-through leachate for a subset of eight plants, two of each combination of salt and $\mathrm{N}$ treatment. We analyzed leachate for total dissolved $\mathrm{N}$ via combustion and luminescent detection (Skalar Formacs TN analyzer, Breda, The Netherlands).

\section{Traits measured}

We measured five traits related to salt tolerance and overall performance for each plant: change in height from beginning to end of treatments $(\mathrm{cm})$ (hereafter, height growth), leaf mass per area or LMA (dry leaf mass in $\mathrm{g} /$ total leaf area $\mathrm{cm}^{2}$ ), succulence (grams of water in all leaves / total leaf area $\mathrm{cm}^{2}$ ), root to shoot ratio based on dry biomass, and total dry biomass (g) at harvest. In addition, we used a LI-COR 6400 to measure maximum photosynthetic rate (micromoles $\mathrm{CO}_{2} / \mathrm{m}^{2} \cdot \mathrm{s}$ ) for a subset of the plants just prior to harvest. We determined that the appropriate photosynthetically active radiation (PAR) for saturation in these plants was 1000 micromoles $\mathrm{PAR} / \mathrm{m}^{2} \cdot \mathrm{s}$ based on light curves generated from six data points from each of two plants (one low salt-no $\mathrm{N}$ and one high salt-high $\mathrm{N}$ ). 
208

209

210

211

212

213

214

215

216

217

218

219

220

221

222

223

224

225

226

\section{7}

228

229

230

231

232

233

234

235

236

237

238

239

240

241

242

243

244

245

246

247

248

249

250

251

252

253

254

We then measured maximum photosynthetic rate on one plant with at least two healthy leaves for each surviving maternal line for each treatment $(n=29$ low salt-no $N, n=31$ high salt-no $N, n=26$ low salt-high $\mathrm{N}$, and $\mathrm{n}=32$ high salt-high $\mathrm{N}$, for total $\mathrm{N}=118$ total plants). We defined healthy leaves as attached, a minimum of $50 \%$ green, and fully developed. We took maximum photosynthetic rate measurements at a $\mathrm{CO}_{2}$ rate of 400 micromoles $/\left(\mathrm{m}^{2} \cdot \mathrm{s}\right)$ and a flow rate of 500 micromoles/s. We took the measurements on a healthy leaf from the second node of each plant after the leaf had been clamped in the LI-COR for one minute to ensure conditions had stabilized. We measured maximum photosynthetic rate for the 118 plants in random order over six consecutive days from April 23-28, 2016, between 8:30 and 11:30 in the morning.

We characterized each plant as alive, dormant, or dead at the end of the experimental treatments. We assigned plants that showed no growth and no desiccation to the dormant category. All live and dormant plants were harvested after six months of treatment. Height growth, succulence, maximum photosynthetic rate, and LMA was only analyzed for alive plants. We only used healthy leaves for succulence, maximum photosynthetic rate, and LMA. We included leaves that were attached, but not $50 \%$ green or fully developed in dry above ground biomass. We measured the biomass of above and below ground tissues of all harvested plants after the tissues were dried at $60^{\circ} \mathrm{C}$ until they maintained constant mass. Finally, we measured the total dry mass of leaves after drying in silica desiccant beads for a minimum of seven days to constant mass.

\section{Statistical analysis}

We performed all statistical analyses in $\mathrm{R}$, version 4.0.3 (R Core Team, 2020). All analyses reported here used either the General Linear Model (GLM) or Generalized Linear-Mixed-Model (GLMM) frameworks. We checked the residuals to assess normality on traits as appropriate; we did not transform height growth or photosynthesis (lmer and glm), but we used the log link function (glmer) for analysis of succulence, LMA, root to shoot ratio, and total biomass. We used the function lmer or glmer implemented within the lme4 package (Bates et al., 2015) to fit a series of models and identify the best fit model for each trait (Table 1). For each trait and for survival we began with a saturated model that included as fixed factors salt, N, and their interaction. For change in height, we included the covariate of height at the beginning of treatments in October. The saturated models also included random effects of block, population and maternal family nested within population. In several cases, models with random terms for block or population failed to converge (Table 1), most likely because there were relatively few blocks and populations. In these cases, we began by treating these as fixed effects. We used Anova (type III) in the package car (Fox and Weisberg, 2019) to evaluate the significance of fixed effects when they were included in the best model.

To gain insight about variance explained by models, we calculated the $R^{2}$ approximations proposed by (Nakagawa and Schielzeth, 2013). As these authors explain, in the context of GLMMs this leads to two different sorts of $R^{2}$, a marginal $R^{2}$ that reflects variance explained by fixed factors only, and a conditional $R^{2}$ that reflects variance explained by both fixed and random factors. We report each of these as appropriate, e.g., where the best model includes only fixed factors we report only the marginal $R^{2}$.

We assessed three survival states that were coded as 0 for live plants, 1 for dormant plants, and 2 for plants that died during the experiment. We modeled survival using random effects logistic regression. In one set of models, we included dormant plants as alive, and in another we excluded them. The results were qualitatively similar, so we report only the case where dormant plants were treated as alive.

This is a provisional file, not the final typeset article 


\section{RESULTS}

\section{Treatment validation}

257

258

259

260

261

262

263

264

265

266

267

268

269

270

271

272

273

274

275

276

277

278

279

280

281

282

283

284

285

286

287

288

289

290

291

292

293

294

295

296

297

298

299

To ensure that our $\mathrm{N}$ amendment treatments were not flushed out during the once weekly flow through watering we measured the total dissolved $\mathrm{N}$ in leachate from a subsample of the seedlings. We found that $\mathrm{N}$ was not significantly different between the low salt-no $\mathrm{N}$ and the high salt-high $\mathrm{N}$ amended plants and, therefore, confirmed that we did not lose the $\mathrm{N}$ due to watering between treatments (Mean Square $=0.11, \mathrm{~F}$ ndf $3 / \mathrm{ddf} 48=0.23, \operatorname{Pr}(>\mathrm{F})=0.88$ ).

\section{Trait responses to treatment}

The only useful predictor among the fixed effects for the change in height is the height at the start of treatments in October (Table 1; marginal $\mathrm{R}^{2}=0.82$; Anova chisq $=4432.67 ; \mathrm{p}<0.0001$ ). The conditional $R^{2}$ is 0.92 , and the marginal $R^{2}$ is 0.82 , indicating that $82 \%$ of the variance in change in height is explained by a positive relationship with the fixed effect of height at the beginning of the experimental treatments (estimate $=0.9009$ ). The variance components (scaled to sum to 1 ) for population and maternal families within populations are $23 \%$ and $37 \%$ of the random variance respectively. A plot of the random effects suggest that the sites are largely similar, with the exception of FD which is very different (Figure S1). It's not obvious that any population has more amongfamily variability, but our design is limited to determine this.

For LMA (log link), the best model included only the random effects of block, population and maternal families within populations. The conditional $R^{2}$ is 0.99 . In this model, maternal family explains $51 \%$ of the variance, population explains $30 \%$ of the variance and block explains $17 \%$ (Figure S2).

For succulence (log link) the best model included the fixed effect of salt and the random effects for family nested within population. The marginal $R^{2}=0.39$, while the conditional $R^{2}=0.99$. The scaled variance components for maternal families within populations and populations are, respectively, 0.91 and 0 ; in other words there is very large variance among maternal families within populations, but not among populations (Figure S3). While increased salt resulted in a statistically meaningful reduction in succulence (Figure 2), it is only when conditioned on family that it adds to the explanatory power of the model.

The best model for total biomass included only the random effects of populations and maternal families within populations. The conditional $R^{2}=0.15$. The terms for populations and families nested within them account for $14 \%$ and $23 \%$ of the random variance, respectively (Figure S5).

Root to shoot biomass ratio was the only variable for which the data supported the saturated model as best model (Figure 2). The conditional $R^{2}=0.134$, while the marginal $R^{2}=0.007$. An Anova to evaluate these fixed effects revealed that the main effects of salt and $\mathrm{N}$ were not individually significant but the interaction was (chisq $=7.24 ; p=0.007$ ). However, the small size of the marginal $R^{2}$ suggests that these effects are mainly meaningful when conditioned on the random terms. The random terms population, population and block account for $12 \%, 18 \%$, and $10 \%$ of the random variance, respectively. For this trait, population WI was different from all the others (Figure S4).

The photosynthesis data were most limited in sample size since we were only able to assess one individual with at least two healthy leaves for each surviving maternal line for each treatment 
300

301

302

303

304

305

306

307

308

309

310

311

312

313

314

315

316

317

318

319

320

321

322

323

324

325

326

327

328

329

330

331

332

333

334

335

336

337

338

339

340

341

342

$(\mathrm{N}=118)$. The best model was one including the fixed effects salt, $\mathrm{N}$, and their interaction, but no random effects (Table 1). As with root to shoot biomass ratio, an Anova to evaluate these fixed effects showed the main effects of salt and $\mathrm{N}$ were not significant but the interaction was (chisq $=$ 4.46; $\mathrm{p}=0.035$ ). At ambient $\mathrm{N}$ levels (no $\mathrm{N}$ added), maximum photosynthetic rate and root-to-shoot ratio both declined with increasing salt concentration, but this negative impact of salt was absent or reversed upon the addition of $\mathrm{N}$ fertilizer (Figure 2B and 2C).

In summary, we found that some combination of salt and $\mathrm{N}$ treatments were included in the best models for three of the six traits we measured. Succulence decreased in response to higher salt (Figure 2A), but this response varied largely by family (Figure S3). For root to shoot biomass ratio and maximum photosynthetic rate the responses to experimental treatments depended on changes in both salt and N (Figure 2B and 2C). Root to shoot ratio also varied by family and population (Figure S4).

\section{Survival}

Of 1149 plants, 76 were unequivocally dead in April, 1073 unequivocally alive, and 166 dormant. The number of plants that showed active growth ranged from 63\% in HI to $91 \%$ in WI (Figure 3). The number of plants that didn't show growth, but also didn't appear to be dead ranged from 3\% in WB and WI to 7\% in UTB. We modeled survival by including these dormant plants alternatively as either alive or dead. In both cases the best-supported model was one including a fixed effect for population and a random effect for maternal family (Figure S7). The model treating dormant plants as alive had conditional $\mathrm{R}^{2}=0.11$ and marginal $\mathrm{R}^{2}=0.08$. The model with dormant plants as dead had conditional $R^{2}=0.28$ and marginal $R^{2}=0.13$. Because there is no residual in the equation defining logistic regression, no variance component for a random residual is calculated, and thus it is not possible to calculate a meaningful scaled variance component for family here.

\section{DISCUSSION}

We assessed the growth and survival of $R$. mangle propagules to full factorial combinations of two salt and two $\mathrm{N}$ levels because these are two important abiotic properties that potentially have important impacts on mangrove biomass and traits and, by extension, on the biodiversity and ecosystem function of coastal wetlands. In addition to natural variation in these conditions, anthropogenic activities may result in more extreme levels of these conditions from runoff and flooding (Antlfinger and Dunn, 1983; Ellison et al., 2005; Krauss et al., 2006; Gedan et al., 2009; Kirwan and Megonigal, 2013; Lewis et al., 2014). We predicted that $R$. mangle seedlings would be plastic in response to salinity and $\mathrm{N}$ amendment in putative adaptive traits that conserve water and adjust allocation of N. Our study showed that only succulence was plastic in response to salt, regardless of $\mathrm{N}$ treatment. Allocation to root and shoot biomass and maximum photosynthetic rate were also plastic, but response of both traits to $\mathrm{N}$ amendment depended on the level of salt. This supported our second prediction that response to salinity and $\mathrm{N}$ amendment will co-vary as plants shift resources to maintain osmotic balance. We also found support for our third prediction that populations would vary in putative adaptive traits, and in plasticity of these traits, due to population differentiation. Importantly, every trait except for photosynthesis varied among population and maternal families within populations. This was also true of survival. In fact, maternal family and population were the most consistent predictors for variation in traits and survival.

\section{Phenotypic plasticity in response to treatments}


343 We expected that $R$. mangle propagule traits and survival would respond to salinity by decreasing growth and respond to $\mathrm{N}$ fertilization by increasing growth. We also expected that $\mathrm{N}$ could alleviate some of the effects of salinity as indicated by an interaction of the two conditions. However, we found no response to treatments in height growth, succulence or total dry biomass. This may be due to the propagules being supported by resources provided by the maternal tree, which in $R$. mangle can support growth for at least a year (Ball, 2002; Proffitt and Travis, 2010). If the seedlings were supported by these maternal reserves, height growth would likely be more correlated to propagule length at collection which would be corrected for in the start-of-experiment (time zero) height measurements that we included as a covariate. Because our treatment duration was only six months, the lack of growth response to treatments is consistent with dependence on maternal reserves. However, we did see seedling response to treatment in succulence, maximum photosynthetic rate and allocation to root and shoot biomass.

Increased succulence is a common response to water deficiency under high salinity conditions (Rosenthal et al., 2002; Vendramini et al., 2002; Ottow et al., 2005; Karrenberg et al., 2006; Richards et al., 2008, 2010), but in our experiment we detected reduced succulence in response to high salt. However, this could be due to the fact that $R$. mangle excludes salt, which may result in a different physiological response to salinity (Cavalieri and Huang, 1979; Donovan et al., 1996; Tester and Davenport, 2003). For example, several other halophytes that are salt excluders, including the succulent plant Salicornia europea L., and another member of Rhizophoraceae, Kandelia candel (L.) Druce, do not increase succulence or leaf thickness in response to high salinity (Glenn and O'Leary, 1984; Kao et al., 2001). In fact, with $\mathrm{N}$ fertilization $K$. candel decreased leaf thickness when salinity was increased (Kao et al., 2001). Thus, one possible explanation for our results is that the $\mathrm{N}$ fertilized seedlings were able to reallocate resources and still maintain turgor and water uptake in the high salt condition without increased succulence.

Although we saw significant plasticity for three of the six traits in response to our treatments, response in only R:S and maximum photosynthetic rate depended on the interaction between salt and $\mathrm{N}$ fertilization. We expected maximum photosynthetic rate to increase in response to $\mathrm{N}$ fertilization because the enzyme RuBisCO, which catalyzes the dark reactions in photosynthesis, requires a large amount of N (Sage et al., 1987; Andersson, 2008). Further, a meta-analysis across different species and biomes showed increased maximum photosynthetic rate with increased N (Walker et al., 2014). This could lead to increased shoot biomass which is supported by our analysis in the absence of salt (i.e. decreased R:S in response to $\mathrm{N}$ ). Despite this expectation, there was no overall response to high $\mathrm{N}$ level independent of salt treatment. One reason might be that photosynthesis was limited by other nutrients, not just $\mathrm{N}$, and thus increasing $\mathrm{N}$ alone might not have been enough to elicit a response. In a field study, dwarf $R$. mangle did not respond to $\mathrm{N}$ alone, but did increase biomass in response to fertilization with $\mathrm{N}$, phosphorus $(\mathrm{P})$, and potassium ions $\left(\mathrm{K}^{+}\right)$, potentially because they were $\mathrm{P}$ limited (Feller, 1995). We also expected that response to $\mathrm{N}$ amendment would depend on salinity. We found that in plants treated with high salt, maximum photosynthetic rate was slightly enhanced by high $\mathrm{N}$. Possibly, the additional $\mathrm{N}$ enabled the plants to synthesize N-rich compatible solutes for osmotic regulation and continue photosynthetic gain of carbon (Flowers and Colmer, 2008). Plants in high salt also responded differently in allocation with increased N; instead of increasing shoot biomass, they increased root biomass on average.

\section{Variation within and among sites}

386 Phenotypic variation that is maintained in common garden from within and among populations 387 would indicate $R$. mangle has heritable trait diversity to adapt to changing environmental conditions. 
388

389

390

391

392

393

394

395

396

397

398

399

400

401

402

403

404

405

406

407

408

409

410

411

412

413

414

415

416

417

418

419

420

421

422

423

424

425

426

427

428

429

430

431

432

433

We found variation in height growth, succulence, R:S, LMA, and total dry biomass was largely determined by maternal families within populations. Seedling survival depended on population and varied among maternal families for all of the six populations. Proffitt and Travis (Proffitt and Travis, 2010) also found seedling survival varied among maternal families, as well as by location in the intertidal zone. But in their study after three years, growth and survival did not reflect initial propagule size (Proffitt and Travis, 2010). Our results support these previous findings that propagule length is positively correlated to short term performance, which suggests that maternal reserves in the $R$. mangle propagule can help the seedling survive, and larger propagules contain more maternal reserves than smaller propagules (Ball, 2002; Proffitt and Travis, 2010). Because our study was a short-term, controlled greenhouse study, maximum photosynthetic rate might be the best indicator for an immediate response. Variation in maximum photosynthetic rate can ultimately manifest as variation in growth and allocation of resources, particularly once the seedling has depleted maternal reserves. The seedlings did not show significant differences in height growth or total dry biomass in response to treatments. But given the plasticity we saw in maximum photosynthetic rate, and the oneyear and three-year growth results found in a previous study of nearby populations (Proffitt and Travis, 2010), it's conceivable that with additional time our seedlings would respond more dramatically to these treatments. However, previous work in several different systems have argued that greenhouse studies are often unable to recreate relevant field conditions so these responses may only be registered in field conditions (Schittko et al., 2016; Rinella and Reinhart, 2017; Forero et al., 2019; Dostál et al., 2020).

The amount of heritable phenotypic diversity and differentiation we discovered in this study is an important indicator of the potential for this species to respond to changing conditions, which may be surprising. We previously reported low genetic diversity among these plants based on molecular markers, which is expected to limit the potential for different responses among individuals. On the other hand, we discovered high epigenetic diversity (Mounger et al., 2021), which could contribute to phenotypic and functional diversity, and could be a mechanism underlying the type of phenotypic differences and plasticity we found here (Zhang et al., 2013; Nicotra et al., 2015; Herrera et al., 2017; Jueterbock et al., 2020). In addition, we know very little about the interactions with the microbiome in the species, but microbes have been highlighted as important symbionts in these and other challenging environments (Bowen et al., 2017; Angermeyer et al., 2018; Jung et al., 2021). Soil microbial activity could have dramatic impacts on the future nutrient availability and stability of these coastal sediments (Deegan et al., 2012; Bowen et al., 2017; Hughes et al., 2020; Lewis et al., 2021). In fact, a recent study suggested that bacterial community composition differed among $R$. mangle maternal genotypes but not with genetic diversity (Craig et al., 2020).

\section{Conclusions}

Mangroves provide many ecosystem services, but their global area has declined between $20 \%$ and 35\% since 1980 (Food and Agriculture Organization of the United Nations, 2007; Global forest resources assessment 2020,2020). In addition to global area decline due to anthropogenic activities, mangroves also face rising sea levels and flooding predicted by climate change (Krauss et al., 2008; IPCC, 2014; Wuebbles et al., 2014; Osland et al., 2017). Previous work suggested that $R$. mangle growth and survival depended on an interaction of intertidal elevation and maternal genotype interaction, suggesting variation in response to flooding conditions (Proffitt and Travis, 2010). This variation among genotypes could be important to enable $R$. mangle to dominate over a larger intertidal range. However, in addition to changes in flooding, anthropogenic activities are causing changes in salinity and $\mathrm{N}$ level in $R$. mangle ecosystems (McKee et al., 2007). The interacting effects of salinity, $\mathrm{N}$ level, and elevation are complex and potentially non-additive (McKee et al., 2007). Our

This is a provisional file, not the final typeset article 
434

435

436

437

438

439

440

441

442

443

444

445

446

447

448

449

450

451

452

453

454

455

456

457

458

459

460

461

462

463

464

465

466

467

468

469

470

471

472

experimental findings suggest that the important traits of succulence, photosynthesis and root to shoot biomass allocation respond to salinity, $\mathrm{N}$ level, or the combination of these conditions, but also the magnitude of responses varies among populations and even maternal families within populations. In addition, $R$. mangle seedling survival depended on maternal family for all of the six sites.

This variation in important traits and survival among families and among populations is particularly interesting given our previous work with genetic markers that showed that these populations had low genetic diversity, and little population differentiation. Considering the importance of this foundation species for the functioning of the coastal ecosystem, the lack of genetic diversity might be alarming. However, accumulating studies provide important evidence that genetic variation must be interpreted with caution (Hufford and Mazer, 2003) and that the emphasis on only variation in DNA sequence can be misguided (Keller, 2002, 2014; Sultan, 2015; Bonduriansky and Day, 2018). Nongenetic sources of response may contribute to the resilience of $R$. mangle and other critical species to changing environmental conditions and contribute to future adaptation to a complex mosaic of environmental conditions.

\section{DATA AVAILABILITY STATEMENT}

All data and scripts will be submitted on zenodo and updated here as soon as possible.

\section{Conflict of Interest}

The authors declare that the research was conducted in the absence of any commercial or financial relationships that could be construed as a potential conflict of interest.

\section{AUTHOR CONTRIBUTIONS}

CLR, KLL, GAF, and DBL conceived the study, and designed the experiments. KLL and JM collected plants and maintained experiments. KLL and GAF analyzed the data. CLR and KLL wrote the first draft of the manuscript. All co-authors provided input and revisions to the manuscript.

\section{FUNDING}

This work was supported by funding from the National Science Foundation (U.S.A.) IOS-1556820 (to CLR) and the Federal Ministry of Education and Research (BMBF; MOPGA Project ID 306055 to CLR).

\section{ACKNOWLEDGMENTS}

We thank Bert Anderson, Sandy Voors, Viviana Penuela Useche, M. Teresa Boquete, Mariano Alverez, and Marta Robertson for their help with analyses and review of earlier versions of this manuscript. We are grateful to Christine Brubaker, Racquel Pancho, Brianna Jerman, Vernetta Williams, Alan Franck, and Mary Mangiapia for their guidance, and Charley's Pizza for great food during greenhouse and plant processing work. We thank Samantha Blonder, Jordan Dollbaum, Maria Nikolopoulos, Shane Palmer, Bradley Biega, Bryan Lotici, Harper Cassidy, Jelena Dosen, Nancy Sheridan, and Dawei Tang for their help in the field and the greenhouse. We thank our friends and family for constant support and encouragement and we acknowledge support by the Open Access Publishing Fund of University of Tübingen. 
Table 1. Model selection. Abbreviations: Fam = maternal family; ht = height; LMA = specific leaf mass (dry mass/area); Photo = maximum photosynthetic rate; Pop = population; RTS = root:shoot biomass ratio; $\mathrm{SNG}=$ number of survivors in April. Terms in parentheses are random terms; (1|term) indicates that a random intercept is estimated for each term. Pop/Fam = maternal families nested within source populations. For some models, Block or Pop were fit as fixed effects if estimation as random effects failed (generally due to the small numbers of blocks and source populations). $\Delta_{\mathrm{AIC}}$ is the difference between the saturated model (or closest model to it when saturated model was singular) and the AIC for the given model.

\section{Height (N=907)}

April ht $\sim$ Oct ht + Salt $* \mathrm{~N}+$ Block $+(1 \mid$ Pop/Fam $)$

AIC

$\Delta_{\text {AIC }}$

April ht $\sim$ Oct ht + Salt $+\mathrm{N}+$ Block $+(1 \mid$ Pop/Fam $)$

$\begin{array}{lll}12 & 4308.4 & 0 \\ 11 & 4306.8 & -1.6 \\ 8 & 4301.8 & -6.7 \\ 6 & 4298.2 & -10.24 \\ 4 & 4297.4 & -10.98\end{array}$

April ht $\sim$ Oct ht + Salt $+\mathrm{N}+(1 \mid$ Pop/Fam $)$

April ht $\sim$ Oct ht + Salt $+(1 \mid$ Pop $/$ Fam $)$

April ht $\sim$ Oct ht $+(1 \mid$ Pop/Fam $)$

LMA ( $\mathbf{N}=\mathbf{8 1 8})$

LMA Salt * N + (1|Pop/Fam $)+(1 \mid$ Block $)$

LMA $\sim$ Salt + N + (1|Pop/Fam $)+(1 \mid$ Block $)$

LMA $\sim$ Salt $+(1 \mid$ Pop/Fam $)$

$\mathrm{LMA} \sim(1 \mid \mathrm{Pop} /$ Fam $)+(1 \mid$ Block $)$

$\begin{array}{lll}8 & -8041.9 & 0 \\ 7 & -8043.9 & -2 \\ 6 & -8045.9 & -4 \\ 5 & -8041.8 & 0.1\end{array}$

\section{Succulence $(\mathbf{N}=\mathbf{8 1 8})$}

Succulence $\sim$ Salt $* N+(1 \mid$ Pop/Fam $)$

$\begin{array}{lll}7 & -6534 & 0 \\ 6 & -6533.5 & 0.5 \\ 5 & -6534.5 & -0.5\end{array}$

Root:shoot biomass ratio ( $\mathrm{N}=1073)$

RTS $\sim$ Salt * N + (1|Pop/Fam $)+(1 \mid$ Block $)$

$\begin{array}{lll}8 & 1255.1 \quad 0\end{array}$

Total biomass $(\mathbf{N}=\mathbf{1 0 7 3})$

Total biomass $\sim$ Salt $* \mathrm{~N}+$ Block $+(1 \mid$ Pop/Fam $)$

Total biomass $\sim$ Salt $* N+(1 \mid$ Pop/Fam $)$

Total biomass $\sim(1 \mid \mathrm{Pop} / \mathrm{Fam})$

$\begin{array}{lll}8 & 4869.7 & 0 \\ 7 & 4867.8 & -0.1 \\ 4 & 4864.5 & -5.2 \\ & & \\ 14 & 592.9 & 0 \\ & & \\ 10 & 587.7 & -5.1 \\ 10 & 585.4 & -7.4 \\ 6 & 580.4 & -12.4 \\ 4 & 578.4 & -14.5 \\ & & \\ & & \\ 9 & 561.32 & 0 \\ 8 & 559.32 & -2 \\ 9 & 562.19 & 0.86 \\ 8 & 560.19 & -1.14 \\ 8 & 560.28 & -1.04 \\ 7 & 558.28 & -3.04 \\ 2 & 560.56 & -0.76\end{array}$

Maximum photosynthetic rate $(\mathrm{N}=118)$

Photosynthesis $\sim$ Salt $*$ N + Pop + Block + (1|Fam $)$

Photosynthesis $\sim$ Salt $* N+$ Site $+(1 \mid$ Fam $)$

Photosynthesis $\sim$ Salt $* \mathrm{~N}+$ Block $+(1 \mid$ Fam $)$

Photosynthesis $\sim$ Salt $* N+(1 \mid$ Fam $)$

Photosynthesis $\sim$ Salt $* \mathrm{~N}$

\section{Survival (N=1149)}

$\mathrm{SNG} \sim$ Salt + Pop $+(1 \mid$ Fam $)+(1 \mid$ Block $)$

$\mathrm{SNG} \sim$ Salt + Pop + (1| Fam $)$

$\mathrm{SNG} \sim \mathrm{N}+\mathrm{Pop}+(1 \mid$ Fam $)+(1 \mid$ Block $)$

$\mathrm{SNG} \sim \mathrm{N}+\mathrm{Pop}+(1 \mid$ Fam $)$

$\mathrm{SNG} \sim \mathrm{Pop}+(1 \mid \mathrm{Fam})+(1 \mid$ Block $)$

$\mathrm{SNG} \sim \mathrm{Pop}+(1 \mid \mathrm{Fam})$

$\mathrm{SNG} \sim(1 \mid \mathrm{Fam})$

This is a provisional file, not the final typeset article 


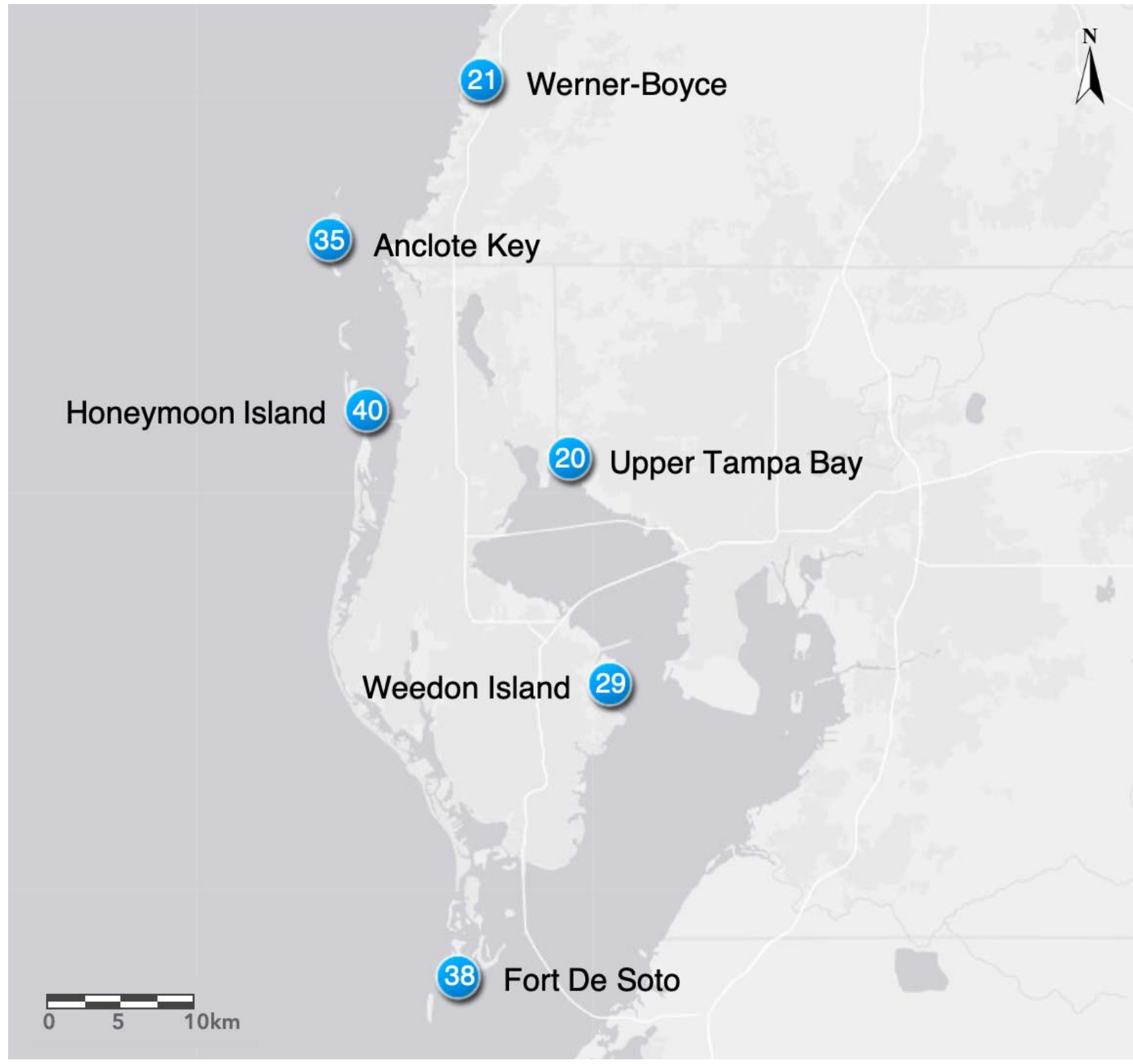

481 Figure 1: We collected Rhizophora mangle propagules from the following sites: Werner-Boyce Salt 482 Springs State Park, Anclote Key Preserves State Park, Honeymoon Island State Park, Upper Tampa 483 Bay Hillsborough County Park, and Weedon Island Preserve Pinellas County Park. Salinity levels (ppt) on the date of collection for each site are indicated within the site location markers. 
A.

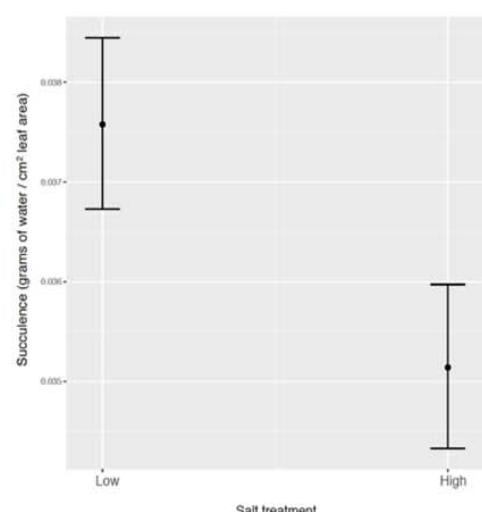

B.

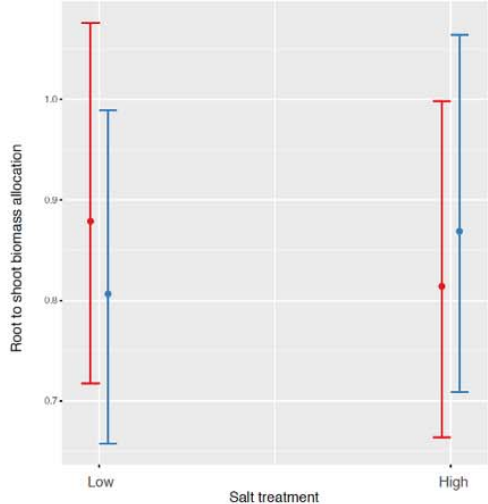

C.

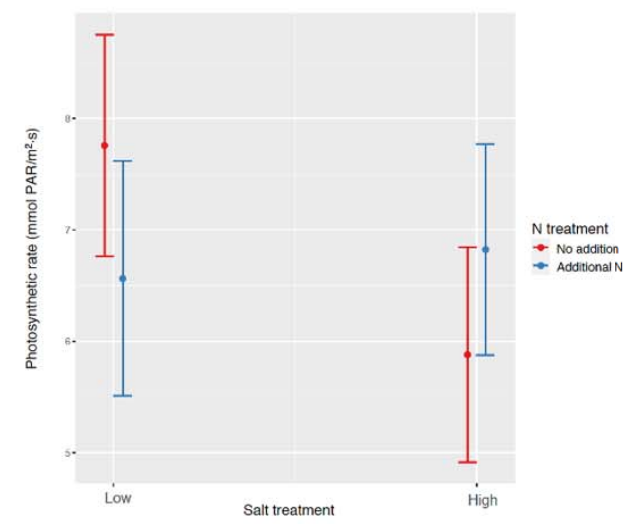

Figure 2. A) Succulence response to salt across populations with no $\mathrm{N}$ effect, including the random effects of maternal families within populations and populations $(\mathrm{N}=818)$. B) root to shoot biomass and $\mathrm{C}$ Photosynthetic rate response to $\mathrm{N}$ depends on salt treatment across all mangrove propagules. The best model for photosynthetic rate $(\mathrm{N}=118)$ does not include any of the random effects. The best model for root to shoot biomass $(\mathrm{N}=1073)$ also includes the random effects of maternal families within populations, populations and block. 


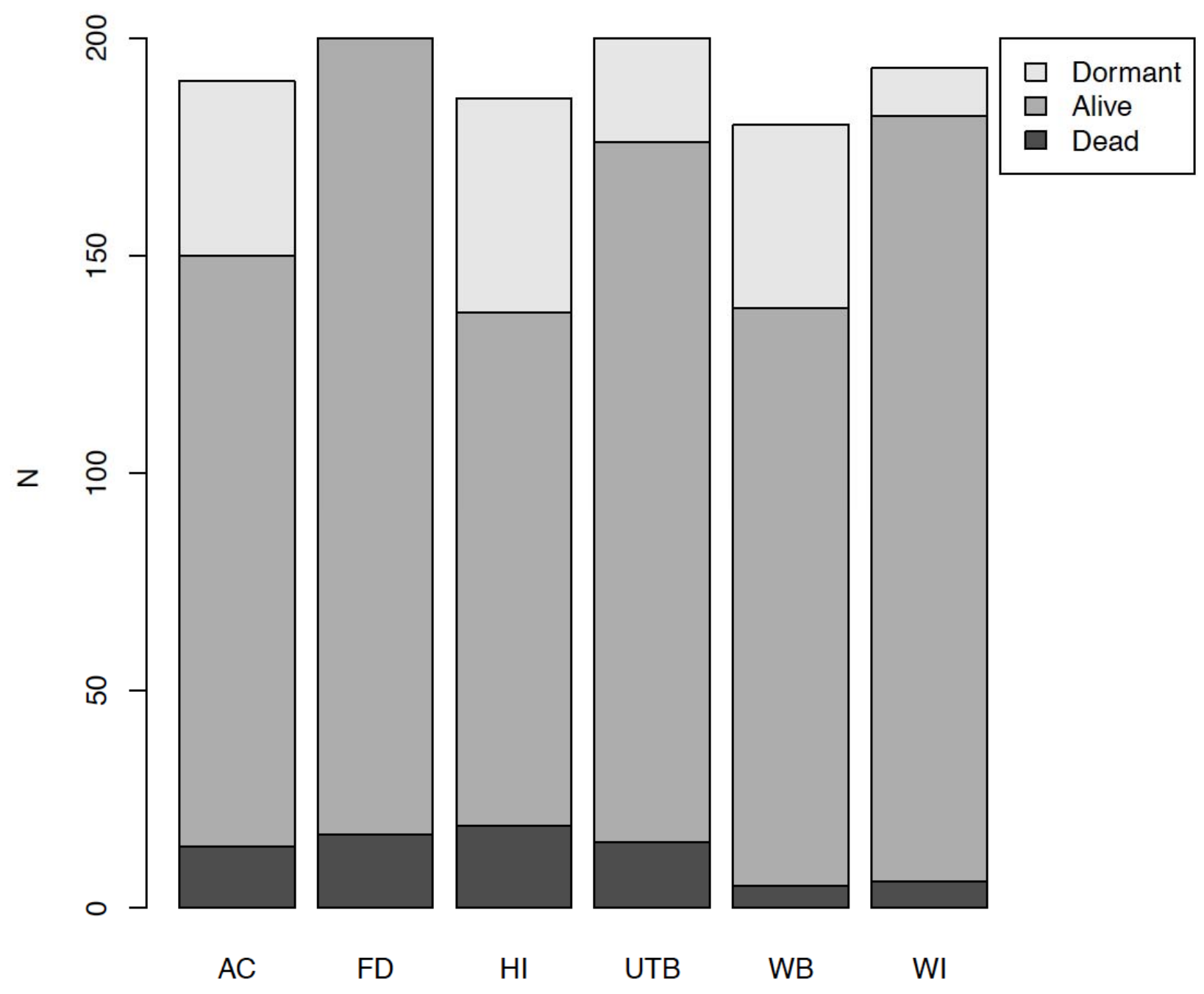

Population

496 Figure 3: Absolute numbers of plants in each growth state at harvest by population of origin.

497 Dormant plants (light gray) showed no signs of desiccation or growth. Seedlings from the HI

498 population had the lowest survival overall, while WI seedlings had the highest survival. Plants alive 499 


\section{Supplementary Material}

\section{Supplemental figures}

A

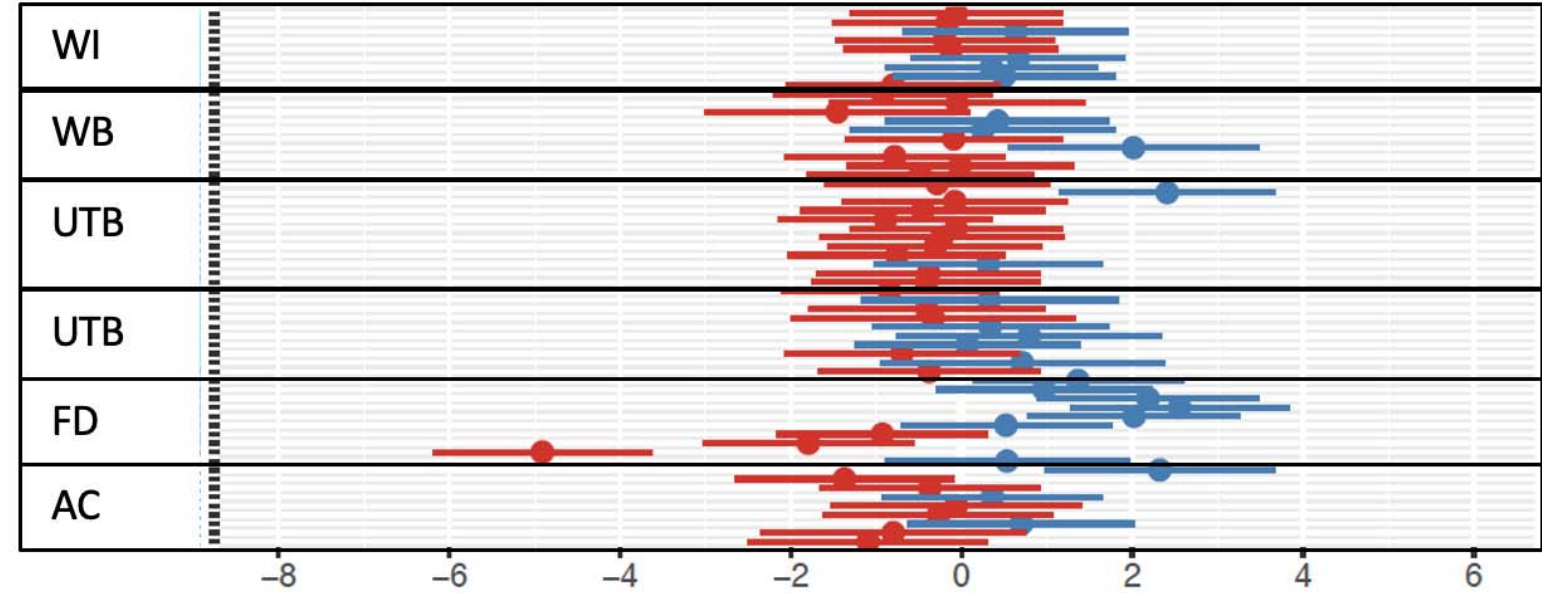

B

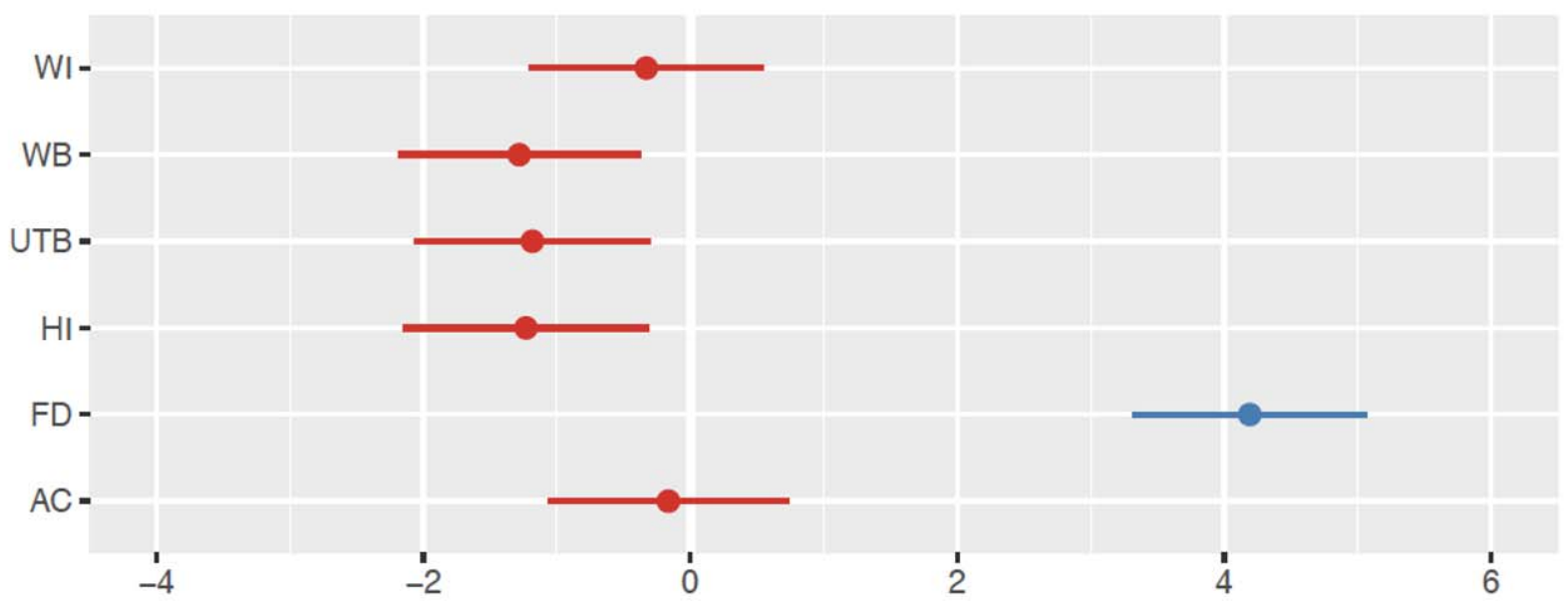

502 Figure S1 Random effects of (A) maternal families and (B) populations on total height. 
A

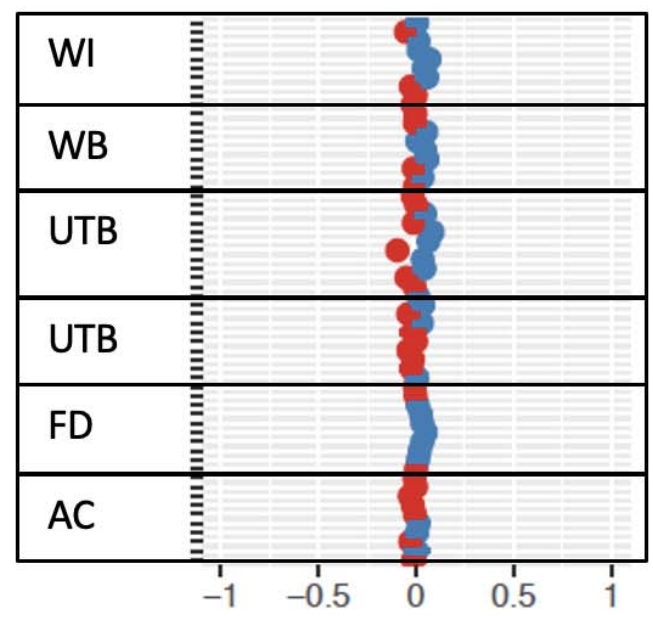

C

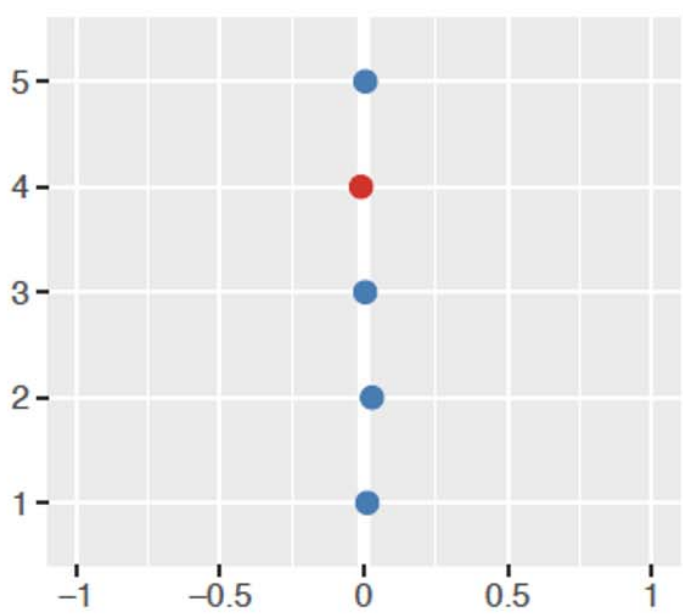

B

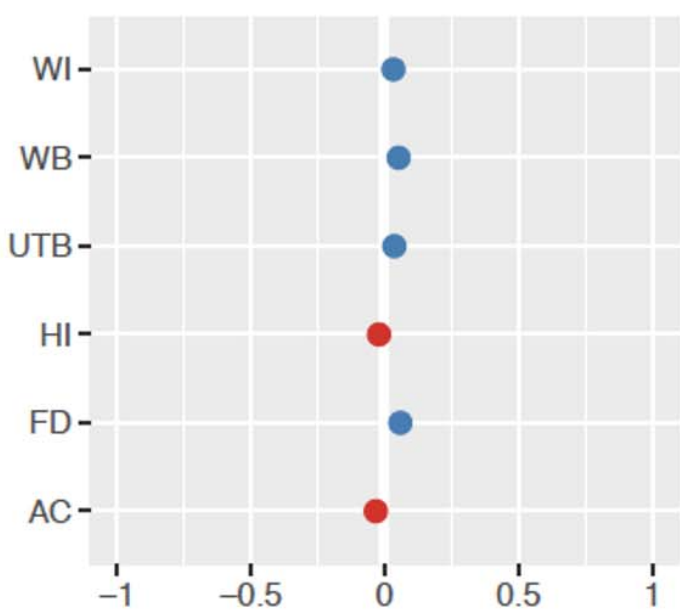

Figure S2 Random effects of (A) maternal families, (B) populations, and (C) blocks on LMA. 
A

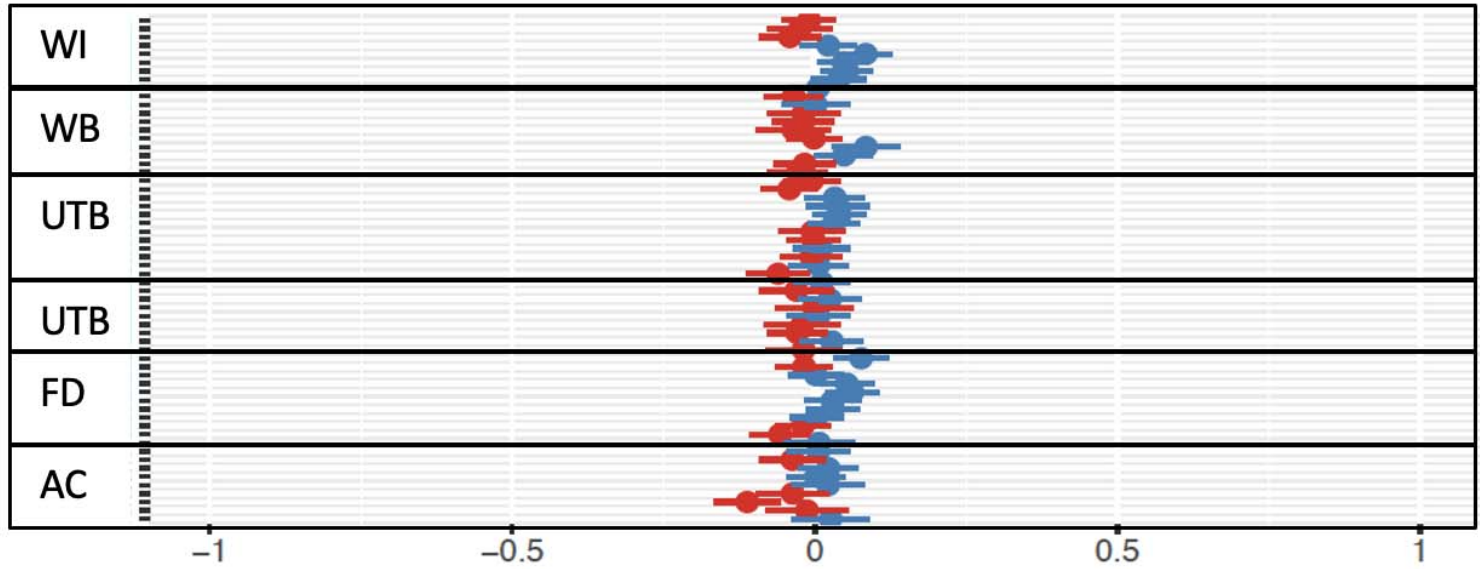

B

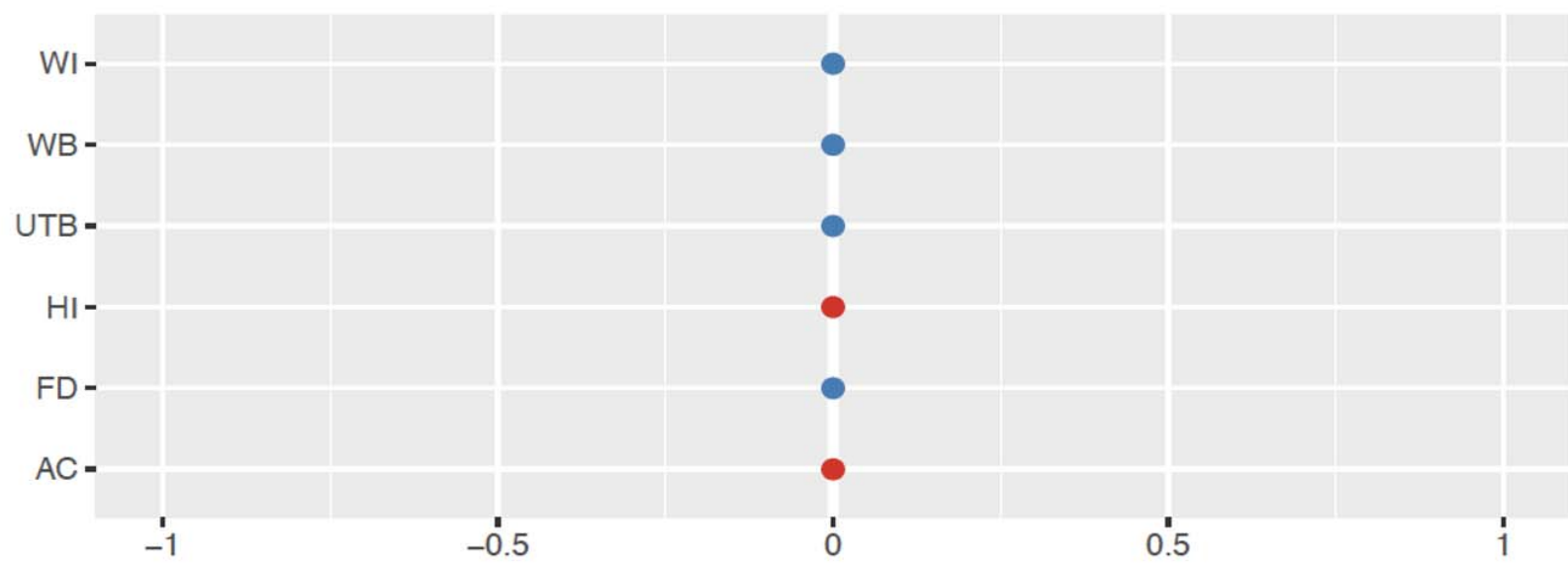

506 Figure S3 Random effects of (A) maternal families and (B) populations on total succulence. 
A

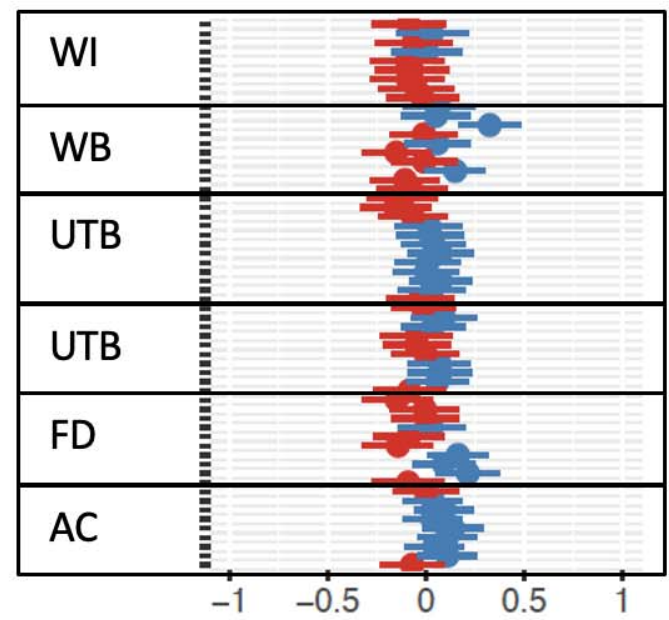

C

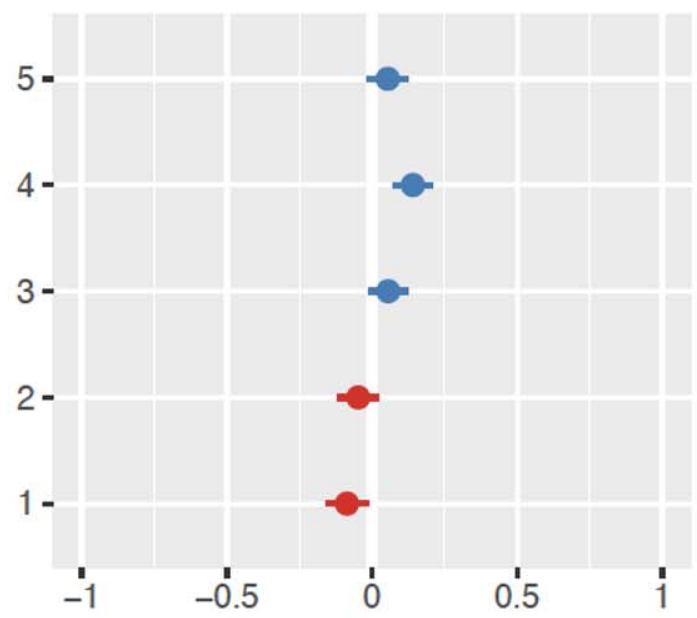

B

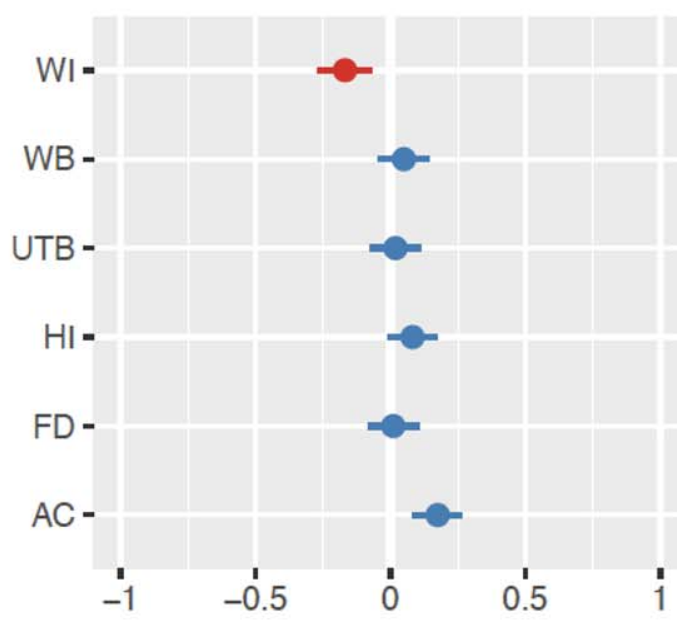

508 Figure S4 Random effects for (A) maternal families, (B) populations, and (C) blocks, in the root-shoot model. 
bioRxiv preprint doi: https://doi.org/10.1101/2021.08.04.454989; this version posted August 6, 2021. The copyright holder for this preprint (which was not certified by peer review) is the author/funder, who has granted bioRxiv a license to display the preprint in perpetuity. It is made available under aCC-BY 4.0 International license.

Plasticity in red mangrove

A

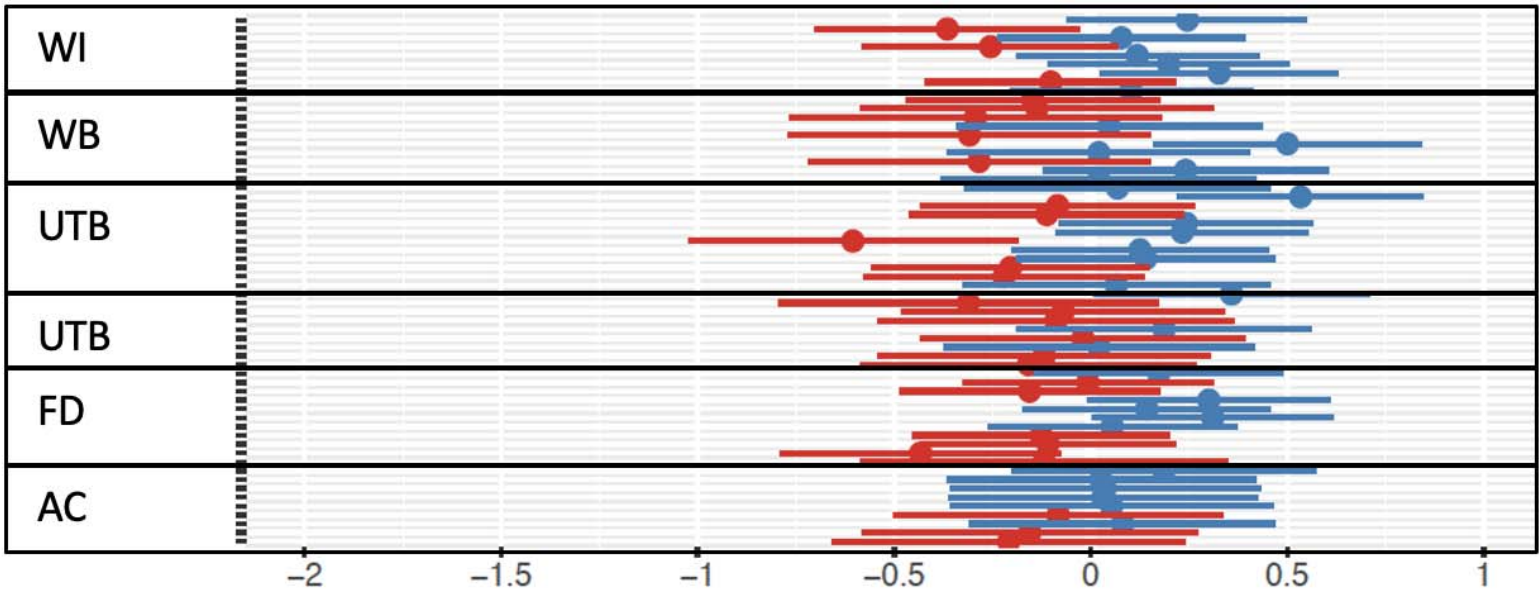

B

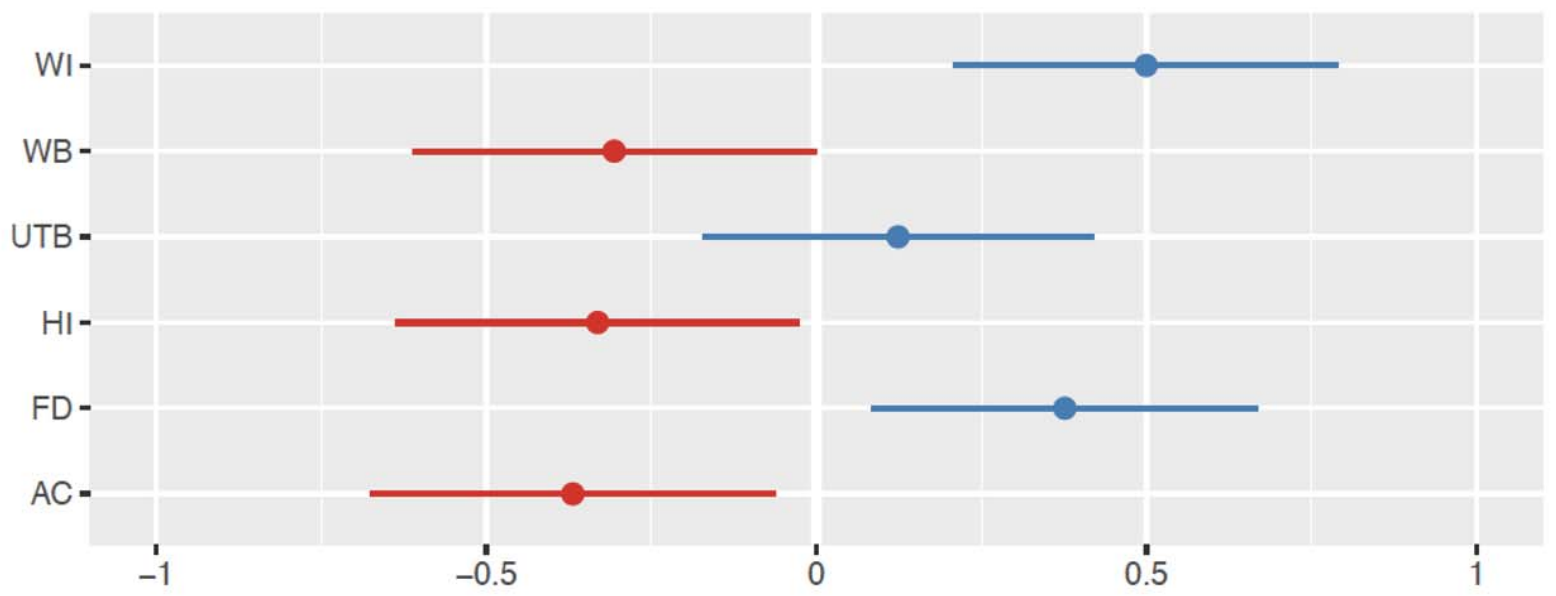

511 Figure S5 Random effects of (A) maternal families and (B) populations on total biomass. 
bioRxiv preprint doi: https://doi.org/10.1101/2021.08.04.454989; this version posted August 6, 2021. The copyright holder for this preprint (which was not certified by peer review) is the author/funder, who has granted bioRxiv a license to display the preprint in perpetuity. It is made available under aCC-BY 4.0 International license.

Plasticity in red mangrove

512

513
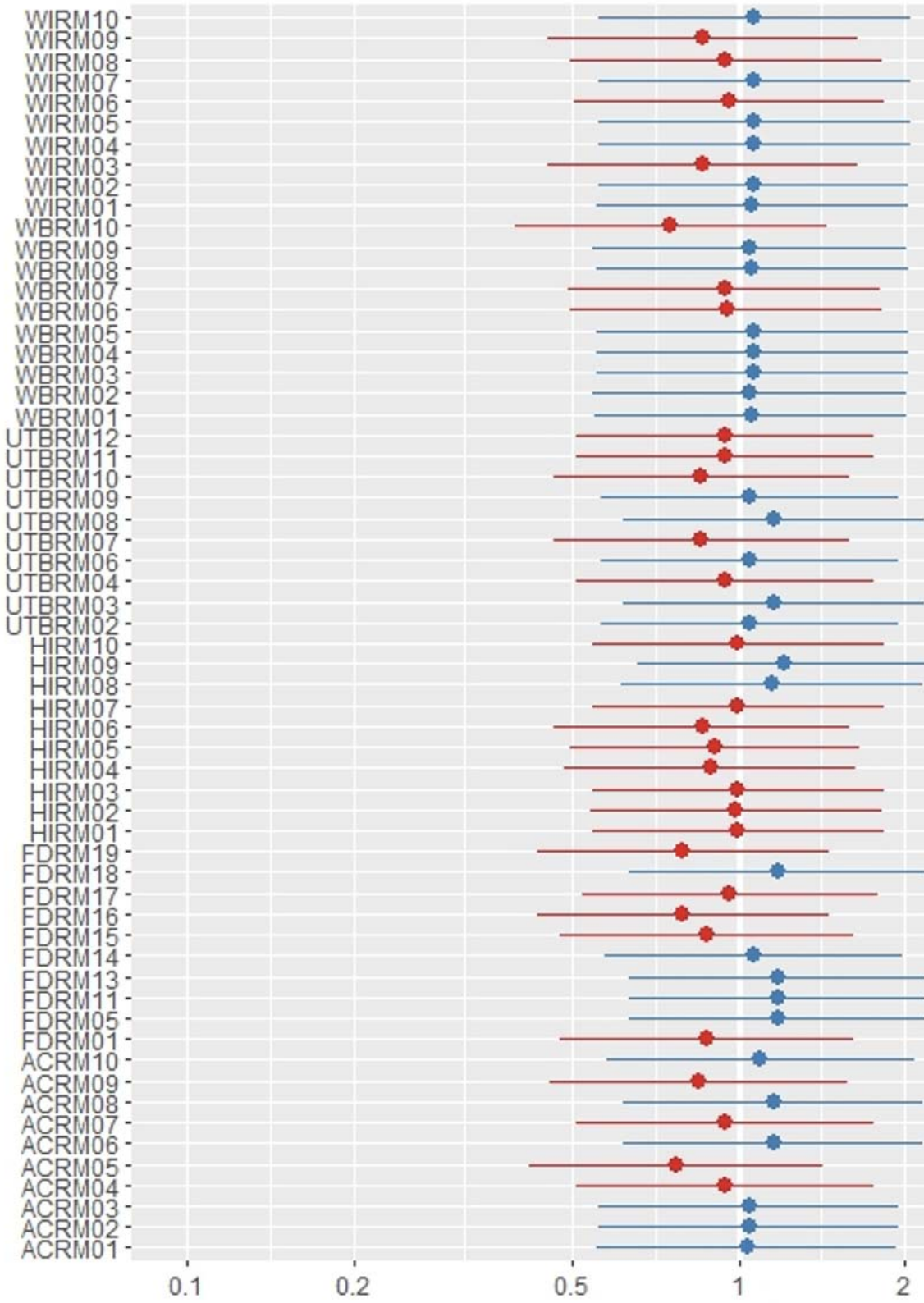

0.1

0.2

0.5

Figure S6 Random effects of maternal families on survival.

514

515

516 


\section{REFERENCES}

518

519

520

521

522

523

524

525

526

527

528

529

530

531

532

533

534

535

536

537

538

539

540

541

542

543

544

545

546

547

548

549

550

551

552

Albrecht, M., Kneeland, K. M., Lindroth, E., and Foster, J. E. (2013). Genetic diversity and relatedness of the mangrove Rhizophora mangle L. (Rhizophoraceae) using amplified fragment polymorphism (AFLP) among locations in Florida, USA and the Caribbean. $J$. Coast. Conserv. 17, 483-491. doi:10.1007/s11852-013-0246-3.

Alongi, D. (2013). Cycling and Global Fluxes of Nitrogen in Mangroves. Global Environmental Research 17, 173-182. Available at: https://www.semanticscholar.org/paper/8d64043c41f098ffc3f36e3a5d50e76203fc794e [Accessed July 10, 2021].

Alongi, D. M. (2008). Mangrove forests: Resilience, protection from tsunamis, and responses to global climate change. Estuar. Coast. Shelf Sci. 76, 1-13. doi:10.1016/j.ecss.2007.08.024.

Andersson, I. (2008). Catalysis and regulation in Rubisco. J. Exp. Bot. 59, 1555-1568. doi:10.1093/jxb/ern091.

Angermeyer, A., Crosby, S. C., and Huber, J. A. (2018). Salt marsh sediment bacterial communities maintain original population structure after transplantation across a latitudinal gradient. PeerJ 6, e4735. doi:10.7717/peerj.4735.

Anisfeld, S. C., and Hill, T. D. (2012). Fertilization effects on elevation change and belowground carbon balance in a Long Island sound tidal marsh. Estuaries Coast. 35, 201-211. doi:10.1007/s12237-011-9440-4.

Antlfinger, A. E., and Dunn, E. L. (1979). Seasonal patterns of CO2 and water vapor exchange of three salt marsh succulents. Oecologia 43, 249-260. doi:10.1007/BF00344952.

Antlfinger, A. E., and Dunn, E. L. (1983). Water use and salt balance in three salt marsh succulents. Am. J. Bot. 70, 561. doi:10.2307/2443167.

Arntz, M. A., and Delph, L. F. (2001). Pattern and process: evidence for the evolution of photosynthetic traits in natural populations. Oecologia 127, 455-467. doi:10.1007/s004420100650.

Ball, M. C. (2002). Interactive effects of salinity and irradiance on growth: implications for mangrove forest structure along salinity gradients. Trees (Berl. West) 16, 126-139. doi:10.1007/s00468-002-0169-3.

Banta, J. A., and Richards, C. L. (2018). Quantitative epigenetics and evolution. Heredity 121, 210224. doi:10.1038/s41437-018-0114-X.

Barbier, E. B., Koch, E. W., Silliman, B. R., Hacker, S. D., Wolanski, E., Primavera, J., et al. (2008). Coastal ecosystem-based management with nonlinear ecological functions and values. Science 319, 321-323. doi:10.1126/science.1150349.

Bates, D., Mächler, M., Bolker, B., and Walker, S. (2015). Fitting linear mixed-effects models Usinglme4. J. Stat. Softw. 67. doi:10.18637/jss.v067.i01. 
Bertness, M. D. (2020). A Brief Natural History of Civilization: Why a Balance Between Cooperation and Competition Is Vital to Humanity. Yale University Press.

Bertness, M. D., and Callaway, R. (1994). Positive interactions in communities. Trends Ecol. Evol. 9, 191-193. doi:10.1016/0169-5347(94)90088-4.

Bertness, M. D., Ewanchuk, P. J., and Silliman, B. R. (2002). Anthropogenic modification of New England salt marsh landscapes. Proc. Natl. Acad. Sci. U. S. A. 99, 1395-1398. doi:10.1073/pnas.022447299.

Bonduriansky, R., and Day, T. (2018). Extended heredity. Princeton, NJ: Princeton University Press.

Bowen, J. L., Kearns, P. J., Byrnes, J. E. K., Wigginton, S., Allen, W. J., Greenwood, M., et al. (2017). Lineage overwhelms environmental conditions in determining rhizosphere bacterial community structure in a cosmopolitan invasive plant. Nat. Commun. 8, 433. doi:10.1038/s41467-017-00626-0.

Bowman, H. H. M. (1917). Ecology and Physiology of the Red Mangrove. Proc. Am. Philos. Soc. 56, 589-672. Available at: http://www.jstor.org/stable/983887.

Caruso, C. M., Maherali, H., Mikulyuk, A., Carlson, K., and Jackson, R. B. (2005). Genetic variance and covariance for physiological traits in Lobelia: are there constraints on adaptive evolution? Evolution 59, 826-837. doi:10.1111/j.0014-3820.2005.tb01756.x.

Cavalieri, A. J., and Huang, A. H. C. (1979). Evaluation of proline accumulation in the adaptation of diverse species of marsh halophytes to the saline environment. Am. J. Bot. 66, 307-312. doi:10.1002/j.1537-2197.1979.tb06228.x.

Costanza, R., Pérez-Maqueo, O., Martinez, M. L., Sutton, P., Anderson, S. J., and Mulder, K. (2008). The value of coastal wetlands for hurricane protection. Ambio 37, 241-248. doi:10.1579/0044-7447(2008)37[241:tvocwf]2.0.co;2.

Craig, H., Kennedy, J. P., Devlin, D. J., Bardgett, R. D., and Rowntree, J. K. (2020). Effects of maternal genotypic identity and genetic diversity of the red mangrove Rhizophora mangle on associated soil bacterial communities: A field-based experiment. Ecol. Evol. 10, 1395713967. doi:10.1002/ece3.6989.

Crosby, S. C., Angermeyer, A., Adler, J. M., Bertness, M. D., Deegan, L. A., Sibinga, N., et al. (2017). Spartina alterniflora biomass allocation and temperature: Implications for salt marsh persistence with sea-level rise. Estuaries Coast. 40, 213-223. doi:10.1007/s12237-016-01429.

Crotty, S. M., Ortals, C., Pettengill, T. M., Shi, L., Olabarrieta, M., Joyce, M. A., et al. (2020). Sealevel rise and the emergence of a keystone grazer alter the geomorphic evolution and ecology of southeast US salt marshes. Proc. Natl. Acad. Sci. U. S. A. 117, 17891-17902. doi:10.1073/pnas.1917869117.

Davis, M. B., and Shaw, R. G. (2001). Range shifts and adaptive responses to Quaternary climate change. Science 292, 673-679. doi:10.1126/science.292.5517.673. 
590

591

592

593

594

595

596

597

598

599

600

601

602

603

604

605

606

607

608

609

610

611

612

613

614

615

616

617

618

619

620

621

622

623

624

625

Deegan, L. A., Johnson, D. S., Warren, R. S., Peterson, B. J., Fleeger, J. W., Fagherazzi, S., et al. (2012). Coastal eutrophication as a driver of salt marsh loss. Nature 490, 388-392. doi:10.1038/nature11533.

DeYoe, H., Lonard, R. I., Judd, F. W., Stalter, R., and Feller, I. (2020). Biological flora of the tropical and subtropical intertidal zone: Literature review for Rhizophora mangle L. J. Coast. Res. 36, 857. doi:10.2112/jcoastres-d-19-00088.1.

Donovan, L. A., Richards, J. H., and Muller, M. W. (1996). Water Relations and Leaf Chemistry of Chrysothamnus nauseosus ssp. Consimilis (Asteraceae) and Sarcobatus vermiculatus (Chenopodiaceae). Am. J. Bot. 83, 1637. doi:10.2307/2445840.

Donovan, L. A., Richards, J. H., and Schaber, E. J. (1997). Nutrient relations of the halophytic shrub, Sarcobatus vermiculatus, along a soil salinity gradient. Plant Soil. Available at: https://link.springer.com/article/10.1023/A:1004211207079.

Dostál, P., Fischer, M., and Prati, D. (2020). Comparing experimental and field $\square$ measured traits and their variability in Central European grassland species. J. Veg. Sci. 31, 561-570. doi:10.1111/jvs.12875.

Ellison, A., Farnsworth, E., and Moore, G. (2015). Rhizophora mangle. IUCN Red List of Threatened Species. doi:10.2305/iucn.uk.2015-1.rlts.t178851a69024847.en.

Ellison, A. M. (2019). Foundation species, non-trophic interactions, and the value of being common. iScience 13, 254-268. doi:10.1016/j.isci.2019.02.020.

Ellison, A. M., Bank, M. S., Clinton, B. D., Colburn, E. A., Elliott, K., Ford, C. R., et al. (2005). Loss of foundation species: consequences for the structure and dynamics of forested ecosystems. Front. Ecol. Environ. 3, 479-486. doi:10.1890/1540-9295(2005)003[0479:lofscf]2.0.co;2.

Feller, I. C. (1995). Effects of nutrient enrichment on growth and herbivory of dwarf red mangrove (Rhizophora mangle). Ecol. Monogr. 65, 477-505. doi:10.2307/2963499.

Feller, I. C., Lovelock, C. E., Berger, U., McKee, K. L., Joye, S. B., and Ball, M. C. (2010). Biocomplexity in mangrove ecosystems. Ann. Rev. Mar. Sci. 2, 395-417. doi:10.1146/annurev.marine.010908.163809.

Feller, I. C., Whigham, D. F., McKee, K. L., and Lovelock, C. E. (2003). Nitrogen limitation of growth and nutrient dynamics in a disturbed mangrove forest, Indian River Lagoon, Florida. Oecologia 134, 405-414. doi:10.1007/s00442-002-1117-z.

Flowers, T. J., and Colmer, T. D. (2008). Salinity tolerance in halophytes. New Phytol. 179, 945-963. doi:10.1111/j.1469-8137.2008.02531.x.

Food and Agriculture Organization of the United Nations (2007). The world's mangroves 1980-2005. A thematic study prepared in the framework of the global forest resources assessment 2005 [2007]. FAO Forestry Paper ( $F A O)$. Available at: https://agris.fao.org/agrissearch/search.do?recordID=XF2008433305.

This is a provisional file, not the final typeset article 
Forero, L. E., Grenzer, J., Heinze, J., Schittko, C., and Kulmatiski, A. (2019). Greenhouse- and fieldmeasured plant-soil feedbacks are not correlated. Front. Environ. Sci. 7. doi:10.3389/fenvs.2019.00184.

Fox, J., and Weisberg, S. (2019). An R Companion to Applied Regression, Third edition. Thousand Oaks, CA : Sage Available at: Https://socialsciences Mcmaster Ca/jfox/books/companion/.

Friess, D. A., Krauss, K. W., Horstman, E. M., Balke, T., Bouma, T. J., Galli, D., et al. (2012). Are all intertidal wetlands naturally created equal? Bottlenecks, thresholds and knowledge gaps to mangrove and saltmarsh ecosystems. Biol. Rev. Camb. Philos. Soc. 87, 346-366. doi:10.1111/j.1469-185x.2011.00198.x.

Gao, L., Geng, Y., Li, B., Chen, J., and Yang, J. (2010). Genome-wide DNA methylation alterations of Alternanthera philoxeroides in natural and manipulated habitats: implications for epigenetic regulation of rapid responses to environmental fluctuation and phenotypic variation. Plant Cell Environ. 33, 1820-1827. doi:10.1111/j.1365-3040.2010.02186.x.

Geber, M. A., and Griffen, L. R. (2003). Inheritance and natural selection on functional traits. Int. J. Plant Sci. 164, S21-S42. doi:10.1086/368233.

Gedan, K. B., Kirwan, M. L., Wolanski, E., and Barbier, E. B. (2011). The present and future role of coastal wetland vegetation in protecting shorelines: answering recent challenges to the paradigm. Clim. Change. Available at: https://link.springer.com/article/10.1007/s10584-0100003-7.

Gedan, K. B., Silliman, B. R., and Bertness, M. D. (2009). Centuries of human-driven change in salt marsh ecosystems. Ann. Rev. Mar. Sci. 1, 117-141. doi:10.1146/annurev.marine.010908.163930.

Glenn, E. P., and O'Leary, W. (1984). Relationship between salt accumulation and water content of dicotyledonous halophytes. Plant Cell Environ. 7, 253-261. doi:10.1111/13653040.ep11589448.

Global forest resources assessment 2020 (2020). FAO doi:10.4060/ca9825en.

Guo, J., Richards, C. L., Holsinger, K. E., Fox, G. A., Zhang, Z., and Zhou, C. (2021). Genetic structure in patchy populations of a candidate foundation plant: a case study of Leymus chinensis (Poaceae) using genetic and clonal diversity. bioRxiv. doi:10.1101/2021.06.12.448174.

Haddad, N. M., Brudvig, L. A., Clobert, J., Davies, K. F., Gonzalez, A., Holt, R. D., et al. (2015). Habitat fragmentation and its lasting impact on Earth's ecosystems. Sci. Adv. 1, e1500052. doi:10.1126/sciadv.1500052.

Herrera, C. M., Medrano, M., and Bazaga, P. (2017). Comparative epigenetic and genetic spatial structure of the perennial herb Helleborus foetidus: Isolation by environment, isolation by distance, and functional trait divergence. Am. J. Bot. 104, 1195-1204. doi:10.3732/ajb.1700162. 
663

664

665

666

667

668

669

670

671

672

673

674

675

676

677

678

679

680

681

682

683

684

685

686

687

688

689

690

691

692

693

694

695

696

697

Hufford, K. M., and Mazer, S. J. (2003). Plant ecotypes: genetic differentiation in the age of ecological restoration. Trends Ecol. Evol. 18, 147-155. doi:10.1016/s0169-5347(03)00002-8.

Hughes, A. R., Moore, A. F. P., and Gehring, C. (2020). Plant response to fungal root endophytes varies by host genotype in the foundation species Spartina alterniflora. Am. J. Bot. 107, 16451653. doi:10.1002/ajb2.1573.

IPCC (2014). Climate Change 2014: Synthesis Report. Contribution of Working Groups I, II and III to the Fifth Assessment Report of the Intergovernmental Panel on Climate Change [Core Writing Team., eds. R. K. Pachauri and L. A. Meyer Geneva, Switzerland: IPCC.

IUCN (2007). Environmental and Socio Economic Value of Mangroves in Tsunami Affected Areas. IUCN- The World Conservation Union Available at: https://www.iwlearn.net/files/pdfs/IUCN\%202007_Mangroves\%20in\%20Tsunami\%20Affect ed\%20Areas.pdf.

Jueterbock, A., Boström, C., Coyer, J. A., Olsen, J. L., Kopp, M., Dhanasiri, A. K. S., et al. (2020). The seagrass methylome is associated with variation in photosynthetic performance among clonal shoots. Front. Plant Sci. 11, 571646. doi:10.3389/fpls.2020.571646.

Jung, J.-H., Reis, F., Richards, C., and Bossdorf, O. (2021). Understanding plant microbiomes requires a G x E framework. EcoEvoRxiv. doi:10.32942/osf.io/bvpyc.

Kao, W.-Y., Tsai, H.-C., and Tsai, T.-T. (2001). Effect of $\mathrm{NaCl}$ and nitrogen availability on growth and photosynthesis of seedlings of a mangrove species, Kandelia candel (L.) Druce. J. Plant Physiol. 158, 841-846. doi:10.1078/0176-1617-00248.

Karrenberg, S., Edelist, C., Lexer, C., and Rieseberg, L. (2006). Response to salinity in the homoploid hybrid species Helianthus paradoxus and its progenitors $\mathrm{H}$. annuus and $\mathrm{H}$. petiolaris. New Phytol. 170, 615-629. doi:10.1111/j.1469-8137.2006.01687.x.

Keith, A. R., Bailey, J. K., Lau, M. K., and Whitham, T. G. (2017). Genetics-based interactions of foundation species affect community diversity, stability and network structure. Proc. Biol. Sci. 284. doi:10.1098/rspb.2016.2703.

Keller, E. F. (2002). The Century of the Gene. Harvard University Press Available at: https://play.google.com/store/books/details?id=N6gomAEACAAJ.

Keller, E. F. (2014). From gene action to reactive genomes. J. Physiol. 592, 2423-2429. doi:10.1113/jphysiol.2014.270991.

Kennedy, J. P., Garavelli, L., Truelove, N. K., Devlin, D. J., Box, S. J., Chérubin, L. M., et al. (2017). Contrasting genetic effects of red mangrove (Rhizophora mangleL.) range expansion along West and East Florida. J. Biogeogr. 44, 335-347. doi:10.1111/jbi.12813.

Kirwan, M. L., and Megonigal, J. P. (2013). Tidal wetland stability in the face of human impacts and sea-level rise. Nature 504, 53-60. doi:10.1038/nature12856.

This is a provisional file, not the final typeset article 
698

699

700

701

702

703

704

705

706

707

708

709

710

711

712

713

714

715

716

717

718

719

720

721

722

723

724

725

726

727

728

729

730

731

732

733

734

Kirwan, M. L., Temmerman, S., Skeehan, E. E., Guntenspergen, G. R., and Fagherazzi, S. (2016). Overestimation of marsh vulnerability to sea level rise. Nat. Clim. Chang. 6, 253-260. doi:10.1038/nclimate2909.

Krauss, K. W., Lovelock, C. E., McKee, K. L., López-Hoffman, L., Ewe, S. M. L., and Sousa, W. P. (2008). Environmental drivers in mangrove establishment and early development: A review. Aquat. Bot. 89, 105-127. doi:10.1016/j.aquabot.2007.12.014.

Krauss, K. W., Twilley, R. R., Doyle, T. W., and Gardiner, E. S. (2006). Leaf gas exchange characteristics of three neotropical mangrove species in response to varying hydroperiod. Tree Physiol. 26, 959-968. doi:10.1093/treephys/26.7.959.

Lewis, D. B., Brown, J. A., and Jimenez, K. L. (2014). Effects of flooding and warming on soil organic matter mineralization in Avicennia germinans mangrove forests and Juncus roemerianus salt marshes. Estuar. Coast. Shelf Sci. 139, 11-19. doi:10.1016/j.ecss.2013.12.032.

Lewis, D. B., Jimenez, K. L., Abd-Elrahman, A., Andreu, M. G., Landry, S. M., Northrop, R. J., et al. (2021). Carbon and nitrogen pools and mobile fractions in surface soils across a mangrove saltmarsh ecotone. Sci. Total Environ. 798, 149328. doi:10.1016/j.scitotenv.2021.149328.

Matesanz, S., Blanco-Sánchez, M., Ramos-Muñoz, M., de la Cruz, M., Benavides, R., and Escudero, A. (2021). Phenotypic integration does not constrain phenotypic plasticity: differential plasticity of traits is associated to their integration across environments. New Phytol. doi:10.1111/nph.17536.

Matesanz, S., and Sultan, S. E. (2013). High-performance genotypes in an introduced plant: insights to future invasiveness. Ecology 94, 2464-2474. doi:10.1890/12-1359.1.

McKee, K. L. (1995). Seedling recruitment patterns in a Belizean mangrove forest: effects of establishment ability and physico-chemical factors. Oecologia 101, 448-460. doi:10.1007/BF00329423.

McKee, K. L., Cahoon, D. R., and Feller, I. C. (2007). Caribbean mangroves adjust to rising sea level through biotic controls on change in soil elevation. Glob. Ecol. Biogeogr. 16, 545-556. doi:10.1111/j.1466-8238.2007.00317.x.

Medina, E., Fernandez, W., and Barboza, F. (2015). Element uptake, accumulation, and resorption in leaves of mangrove species with different mechanisms of salt regulation. Web Ecol. 15, 3-13. doi:10.5194/we-15-3-2015.

Melillo, J. M., Richmond, T. (T C. )., and Yohe, G. W. (2014). Climate change impacts in the United States: The third national climate assessment. , eds. J. M. Melillo, T. (T C. ). Richmond, and G. W. Yohe U.S. Global Change Research Program doi:10.7930/j0z31wj2.

Mounger, J., Teresa Boquete, M., Schmid, M. W., Granado, R., Robertson, M. H., Voors, S. A., et al. (2021). Inheritance of DNA methylation differences in the mangrove Rhizophora mangle.

Evol. Dev. doi:10.1111/ede.12400. 
735

736

737

738

739

740

741

742

743

744

745

746

747

748

749

750

751

752

753

754

755

756

757

758

759

760

761

762

763

764

765

766

767

768

769

770

771

Nadia, T. L., and Machado, I. C. (2014). Wind pollination and propagule formation in Rhizophora mangle L. (Rhizophoraceae): resource or pollination limitation? An. Acad. Bras. Cienc. 86, 229-238. doi:10.1590/0001-37652014101712.

Nakagawa, S., and Schielzeth, H. (2013). A general and simple method for obtainingR2from generalized linear mixed-effects models. Methods Ecol. Evol. 4, 133-142. doi:10.1111/j.2041-210x.2012.00261.x.

Nicotra, A. B., Atkin, O. K., Bonser, S. P., Davidson, A. M., Finnegan, E. J., Mathesius, U., et al. (2010). Plant phenotypic plasticity in a changing climate. Trends Plant Sci. 15, 684-692. doi:10.1016/j.tplants.2010.09.008.

Nicotra, A. B., Segal, D. L., Hoyle, G. L., Schrey, A. W., Verhoeven, K. J. F., and Richards, C. L. (2015). Adaptive plasticity and epigenetic variation in response to warming in an Alpine plant. Ecol. Evol. 5, 634-647. doi:10.1002/ece3.1329.

Osland, M. J., Enwright, N., Day, R. H., and Doyle, T. W. (2013). Winter climate change and coastal wetland foundation species: salt marshes vs. mangrove forests in the southeastern United States. Glob. Chang. Biol. 19, 1482-1494. doi:10.1111/gcb.12126.

Osland, M. J., Griffith, K. T., Larriviere, J. C., Feher, L. C., Cahoon, D. R., Enwright, N. M., et al. (2017). Assessing coastal wetland vulnerability to sea-level rise along the northern Gulf of Mexico coast: Gaps and opportunities for developing a coordinated regional sampling network. PLoS One 12, e0183431. doi:10.1371/journal.pone.0183431.

Ottow, E. A., Brinker, M., Teichmann, T., Fritz, E., Kaiser, W., Brosché, M., et al. (2005). Populus euphratica displays apoplastic sodium accumulation, osmotic adjustment by decreases in calcium and soluble carbohydrates, and develops leaf succulence under salt stress. Plant Physiol. 139, 1762-1772. doi:10.1104/pp.105.069971.

Parmesan, C. (2006). Ecological and evolutionary responses to recent climate change. Annu. Rev. Ecol. Evol. Syst. Available at: https://www.annualreviews.org/doi/abs/10.1146/annurev.ecolsys.37.091305.110100.

Pennings, S. C., and Bertness (2001). "Salt Marsh Communities," in Marine Community Ecology, eds. Bertness, S. D. Gaines, and M. Hay (Sinauer Associates, Sunderland Massachusetts.), 289-316.

Polidoro, B. A., Carpenter, K. E., Collins, L., Duke, N. C., Ellison, A. M., Ellison, J. C., et al. (2010). The loss of species: mangrove extinction risk and geographic areas of global concern. PLoS One 5, e10095. doi:10.1371/journal.pone.0010095.

Proffitt, C. E., and Travis, S. (2014). Red mangrove life history variables along latitudinal and anthropogenic stress gradients. Ecol. Evol. 4, 2352-2359. doi:10.1002/ece3.1095.

Proffitt, C. E., and Travis, S. E. (2005). Albino mutation rates in red mangroves (Rhizophora mangle L.) as a bioassay of contamination history in Tampa Bay, Florida, USA. Wetlands (Wilmington) 25, 326-334. doi:10.1672/9.

This is a provisional file, not the final typeset article 
772

773

774

775

776

777

778

779

780

781

782

783

784

785

786

787

788

789

790

791

792

793

794

795

796

797

798

799

800

801

802

803

804

805

806

807

808

Proffitt, C. E., and Travis, S. E. (2010). Red mangrove seedling survival, growth, and reproduction: Effects of environment and maternal genotype. Estuaries Coast. 33, 890-901. doi:10.1007/s12237-010-9265-6.

Qiao, X., Zhang, J., Wang, Z., Xu, Y., Zhou, T., Mi, X., et al. (2021). Foundation species across a latitudinal gradient in China. Ecology 102, e03234. doi:10.1002/ecy.3234.

R Core Team (2020). R: A language and environment for statistical computing. Vienna, Austria: R Foundation for Statistical Computing Available at: https://www.R-project.org/.

Raju Aluri, J. S. (2013). Reproductive ecology of mangrove flora: Conservation and management. Transylvanian Rev. Syst. Ecol. Res. 15, 133-184. doi:10.2478/trser-2013-0026.

Richards, C. L., Bossdorf, O., Muth, N. Z., Gurevitch, J., and Pigliucci, M. (2006). Jack of all trades, master of some? On the role of phenotypic plasticity in plant invasions. Ecol. Lett. 9, 981993. doi:10.1111/j.1461-0248.2006.00950.x.

Richards, C. L., Pennings, S. C., and Donovan, L. A. (2005). Habitat range and phenotypic variation in salt marsh plants. Plant Ecol. Available at: https://link.springer.com/article/10.1007/s1 1258-004-0841-3.

Richards, C. L., Schrey, A. W., and Pigliucci, M. (2012). Invasion of diverse habitats by few Japanese knotweed genotypes is correlated with epigenetic differentiation. Ecol. Lett. 15, 1016-1025. doi:10.1111/j.1461-0248.2012.01824.x.

Richards, C. L., Walls, R. L., and Bailey, J. P. (2008). Plasticity in salt tolerance traits allows for invasion of novel habitat by Japanese knotweed sl (Fallopia japonica and F.xbohemica, Polygonaceae). American Journal of. Available at: https://bsapubs.onlinelibrary.wiley.com/doi/abs/10.3732/ajb.2007364.

Richards, C. L., Wares, J. P., and Mackie, J. A. (2010). Evaluating adaptive processes for conservation and management of estuarine and coastal resources. Available at: https://link.springer.com/article/10.1007/s12237-010-9306-1.

Rinella, M. J., and Reinhart, K. O. (2017). Mixing soil samples across experimental units ignores uncertainty and generates incorrect estimates of soil biota effects on plants: Response to Cahill et al. (2017) "No silver bullet: different soil handling techniques are useful for different research questions, exhibit differential type I and II error rates, and are sensitive to sampling intensity." New Phytol. 216, 15-17. doi:10.1111/nph.14432.

Rosenthal, D. M., Schwarzbach, A. E., Donovan, L. A., Raymond, O., and Rieseberg, L. H. (2002). Phenotypic Differentiation between Three Ancient Hybrid Taxa and Their Parental Species. Int. J. Plant Sci. 163, 387-398. doi:10.1086/339237.

Sage, R. F., Pearcy, R. W., and Seemann, J. R. (1987). The nitrogen use efficiency of C(3) and C(4) plants : III. Leaf nitrogen effects on the activity of carboxylating enzymes in Chenopodium album (L.) and Amaranthus retroflexus (L.). Plant Physiol. 85, 355-359. doi:10.1104/pp.85.2.355. 
809

810

811

812

813

814

815

816

817

818

819

820

821

822

823

824

825

826

827

828

829

830

831

832

833

834

835

836

837

838

839

840

841

842

843

844

845

Schittko, C., Runge, C., Strupp, M., Wolff, S., and Wurst, S. (2016). No evidence that plant-soil feedback effects of native and invasive plant species under glasshouse conditions are reflected in the field. J. Ecol. 104, 1243-1249. doi:10.1111/1365-2745.12603.

Schuerch, M., Spencer, T., Temmerman, S., Kirwan, M. L., Wolff, C., Lincke, D., et al. (2018). Future response of global coastal wetlands to sea-level rise. Nature 561, 231-234. doi:10.1038/s41586-018-0476-5.

Smith, S. M., and Snedaker, S. C. (1995). Salinity responses in two populations of viviparous Rhizophora mangle L. seedlings. Biotropica 27, 435. doi:10.2307/2388955.

Sultan, S. E. (2001). PHENOTYPIC PLASTICITY FOR FITNESS COMPONENTS IN POLYGONUM SPECIES OF CONTRASTING ECOLOGICAL BREADTH. Ecology. Available at: https://esajournals.onlinelibrary.wiley.com/doi/abs/10.1890/00129658(2001)082[0328:PPFFCI]2.0.CO;2.

Sultan, S. E. (2015). Organism and Environment: Ecological Development, Niche Construction, and Adaptation. Oxford University Press Available at: https://play.google.com/store/books/details?id=YG4VDAAAQBAJ.

Tester, M., and Davenport, R. (2003). Na+ tolerance and Na+ transport in higher plants. Ann. Bot. 91, 503-527. doi:10.1093/aob/mcg058.

Tomlinson, P. B. (2016). The Botany of Mangroves. Cambridge University Press doi:10.1017/CBO9781139946575.

Turner, R. E. (2011). Beneath the salt marsh canopy: Loss of soil strength with increasing nutrient loads. Estuaries Coast. 34, 1084-1093. doi:10.1007/s12237-010-9341-y.

Vendramini, F., Díaz, S., Gurvich, D. E., Wilson, P. J., Thompson, K., and Hodgson, J. G. (2002). Leaf traits as indicators of resource $\square$ use strategy in floras with succulent species. New Phytol. 154, 147-157. doi:10.1046/j.1469-8137.2002.00357.x.

Verhoeven, K. J. F., Van Dijk, P. J., and Biere, A. (2010). Changes in genomic methylation patterns during the formation of triploid asexual dandelion lineages. Mol. Ecol. 19, 315-324. doi:10.1111/j.1365-294X.2009.04460.x.

Walker, A. P., Beckerman, A. P., Gu, L., Kattge, J., Cernusak, L. A., Domingues, T. F., et al. (2014). The relationship of leaf photosynthetic traits - V cmax and $\mathrm{J}$ max - to leaf nitrogen, leaf phosphorus, and specific leaf area: a meta-analysis and modeling study. Ecol. Evol. 4, 32183235. doi:10.1002/ece3.1173.

Wise, R. R., and Juncosa, A. M. (1989). Ultrastructure of the transfer tissues during viviparous seedling development in Rhizophora mangle (Rhizophoraceae). Am. J. Bot. 76, 1286-1298. doi:10.1002/j.1537-2197.1989.tb15110.x.

Wuebbles, D., Meehl, G., Hayhoe, K., Karl, T. R., Kunkel, K., Santer, B., et al. (2014). CMIP5 climate model analyses: Climate extremes in the United States. Bull. Am. Meteorol. Soc. 95, 571-583. doi:10.1175/bams-d-12-00172.1. 
846 Zedler, J. B., and Kercher, S. (2005). WETLAND RESOURCES: Status, trends, ecosystem services, and restorability. Annu. Rev. Environ. Resour. 30, 39-74.

849 Zhang, Y.-Y., Fischer, M., Colot, V., and Bossdorf, O. (2013). Epigenetic variation creates potential for evolution of plant phenotypic plasticity. New Phytol. 197, 314-322. doi:10.1111/nph.12010. 